\title{
What Happened to Unequal Treaties? The Continuities of Informal Empire
}

\author{
MATTHEW CRAVEN*
}

\begin{abstract}
"The barbarians are like beasts and not to be ruled on the same principles as Chinese. Were one to attempt to control them by the great maxims of reason it would tend to nothing but the greatest confusion. The ancient sovereigns well understood this and accordingly ruled barbarians by misrule ... to rule barbarians by misrule was the true and best way of ruling them."

[Confucian maxim attributed to Su Tung-po, cited in H. Morse, The International Relations of the Chinese Empire (London: Longmans, 1910) I, p. 111]

"[As a consequence of its engagements with the West] China has been compelled to abandon its inveterate anti-commercial and antisocial principles, and to acknowledge the independence and equality of other nations in the mutual intercourse of war and peace."

[H. Wheaton, Elements of International Law (Boyd A. 2nd ed. 1880) p. 20]
\end{abstract}

\section{Introduction}

The phenomenon of unequal treaties appears to have largely evaporated as an issue from the domain of international law. ${ }^{1}$ It is typically rendered as an issue impressed alternatively with the particularities of the colonial relationship between European powers and polities on the periphery during the

\footnotetext{
* Reader in International Law, University of London.

${ }^{1}$ On unequal treaties generally see F. Nozari, Unequal Treaties In International Law (1971) p. 286; I. Detter, 'The Problem of Unequal Treaties', 15 International and Comparative Law Quarterly (1966) 1069, pp. 1081-2; A. Lester, 'Bizerta and the Unequal Treaty Theory', 11 International and Comparative Law Quarterly (1962) p. 847; L. Caflisch, 'Unequal Treaties', 35 German Yearbook of International Law (1992) p. 52.
} 
19th Century, ${ }^{2}$ or with the heretical claims of socialist jurists in the middle of the 20th Century. ${ }^{3}$ Its historical specificity, in this respect, has led most recent authors to the view that the phenomenon currently plays no role in international law. ${ }^{4}$ For some, furthermore, it has never done. ${ }^{5}$ Current literature on the law of treaties tends, therefore, typically only to refer in passing to the 'problem of unequal treaties' quickly moving on to the more pressing, and apparently more difficult and enduring, questions of validity, revision, and change.

There is an initial curiosity here. On the one hand there is recognition of the concept as one of historical significance (albeit one whose precise boundaries were never clearly delineated); on the other, there is a simultaneous denial of that history as having any purchase on current mappings of treaty relations or treaty law. There is little doubt that the debates over the 'unequal treaties' negotiated with Japan, China and Siam, for example, occupied the minds of international lawyers for some considerable period of time (and well into the 20th Century). ${ }^{6}$ This was neither a passing curiosity, nor thought

\footnotetext{
${ }^{2}$ The doctrine has been explained as a product of "the self-interested positions for a regime that was a newcomer to the international legal order, dissatisfied with its content but too weak to change its rules." J. deLisle, 'China's Approach to International Law: A Historical Perspective', 94 Proceedings of the American Society of International Law (2000) p. 272.

${ }^{3}$ For the view that the Chinese position in relation to unequal treaties was in part a consequence of soviet doctrine see G. Scott, Chinese Treaties: The Post-Revolutionary Restoration of International Law and Order (Oceana, NY, 1975) pp. 85-92. On the position in soviet doctrine see e.g., Kozhenvnikov who suggests that "the classics of Marxism-Leninism did not extend the rule of international law which says that international treaties should be observed to annexationist and enslaving agreements", cited in W. Kulski, "Soviet Comments on International Law and Relations', 48 American Journal of International Law (1954) p. 640; T. Schweisfurth, Der internationale Vertrag in der modernen sowjetischen Völkerrechtstheorie (1968) pp. 214-220. For a discussion of the Soviet position see Detter, supra note 1.

${ }^{4}$ Reuter, for example, makes no mention of unequal treaties other than by way of referring to Article 52 Vienna Convention on the Law of Treaties (P. Reuter, Introduction to the Law of Treaties, (Keegan Paul, London, 1995)). Caflisch maintains, further, that the unequal treaty doctrine serves only as a 'political' argument possessing no legal status per se, supra note 1, p. 78.

${ }_{5}$ See e.g., A. Aust, Modern Treaty Law and Practice (Cambridge University Press, Cambridge, 2000) p. 257; P. Mushkat, 'The International Legal Status of Hong Kong under Post-Transitional Rule', 10 Houston Journal of International Law (1987-88) p. 2; I. Brownlie, Principles of Public International Law (Oxford University Press, 5th ed., 1998) p. 620; Caflisch, supra note 1, pp. 52-80.

${ }^{6}$ See generally, G. Gong The Standard of Civilization in International Society (Clarendon Press, Oxford, 1984). Most of the literature tended to focus upon the regimes of extraterritoriality and consular jurisdiction to which those treaties gave rise. See e.g., F. Piggott, Extraterritoriality: The Law Relating to Consular Jurisdiction and to Residence in Oriental Countries (Kelly and Walsh, Hong Kong, 1907); F. Hinkley, American Consular Jurisdiction in the Orient (1906); S. Turner, Extraterritoriality in China (London, 1929); H. Woodhead, Extraterritoriality in China: the Case Against Abolition (Tientsin, 1929); F. Jones,
} 
to be exaggerated or exceptional. At the same time, it appears to have been supposed that the phenomenon of unequal treaties has largely been overwritten by subsequent events - whether that be the ending of the formal colonial relationships that initially gave rise to the problem of unequal treaties, or in the development of new treaty rules that effectively 'resolve' the problem. Either way, the phenomenon seems to have been consigned to the dustbin of 'redundant ideas'.

It is not the purpose of this paper to advance the resurrection of unequal treaties as a doctrinal category, nor make any particular suggestions as to how the problem of inequality might be addressed within the corpus of existing treaty law. Rather, the intention is simply to explore what happened to it - to advance what might be called a speculative narrative that seeks to interrogate the reasons why the concept (or phenomenon if you prefer) has been so comprehensively denied a place in our current imaginings of international law. Why is it, in other words, that the problem of unequal treaties which occupied such significance in the relations between States in the late 19th Century, and which fuelled such strong anti-imperialist and nationalist sentiment within the States affected, lost its meaning? What justifies the refusal to speak about equality or inequality in the context of the law of treaties? A secondary objective that follows from this is to think about the implications of this conceptual jettisoning, or temporal confinement, for our current understandings of international law. What is entailed by our current reluctance to think about treaties in terms of equality or inequality? Why has this particular history, as opposed to other historical narratives which retain their salience, been set aside? What does this say about how we approach such issues?

\section{Some Initial Responses}

Two obvious explanations may be presented for why the phenomenon of unequal treaties no longer seems to have significance in international law: one conceptual, one historical. The first is that, as an idea, the question of inequality in the context of treaty-making is incoherent. Every treaty, in some respect, is a manifestation of inequality - whether understood in terms

Extraterritoriality in Japan and the Diplomatic Relations Resulting in its Abolition, 1853-1899 (1931); W. Fishel, The End of Extraterritoriality in China (New York, Octagon, 1952); W. Willoughby, China at the Conference: A Report (Johns Hopkins, Baltimore, 1922); G. Keeton, The Development of Extraterritoriality in China (Longmans, London, 1928); C. Denby, 'Extraterritoriality in China', 18 American Journal of International Law (1924) 667; J. Vincent, The Extraterritorial System in China: Final Phase (Harvard University Press, Cambridge, Mass. 1970). 
of a substantive lack of equilibrium in the respective burdens and benefits, or in terms of the unequal bargaining power of the contracting parties. To say that some treaties are 'unequal', and others not, is therefore either manifestly wrong or simply question-begging. ${ }^{7}$ To this may be added the standard legal defence: to begin to interrogate the validity or otherwise of agreements concluded on the basis of some hypothesised inequality would, in absence of some substantive agreement as to what forms of inequality are tolerable or intolerable, ultimately undermine the conditions for certainty and stability in international relations. At what precise point would inequalities in power and influence be such as to invalidate an agreement? What types of power or influence are relevant? How would one measure them? Would, furthermore, a requirement of a substantive equilibrium in benefits and burdens preclude formal concessions designed to bolster the position of weaker parties? ${ }^{8}$

Such an argument may also be turned in the opposite direction. Far from simply being unavoidable, a presumption of equality might be thought actually beneficial. ${ }^{9}$ It serves to 'flatten' power relations within the framework of the agreement, confining their operation to the moment of negotiation, excluding their salience thereafter. Even if the terms of an agreement were concluded in a context of inequality, so the argument may go, once the agreement has been ratified, both parties are treated on the same basis: both are equally bound, both equally charged with performing their part of the agreement in good faith, both competent to interpret the agreement, both equally liable for failure to comply with its terms. ${ }^{10}$ This insistence upon equality in the legal form, furthermore, seems to affirm a more general commitment to the regulative ideal of inclusive political pluralism - excluding a hierarchical ordering of international society or a politics of exclusion. ${ }^{11}$

\footnotetext{
${ }^{7}$ Caflisch remarks, for example, that "it is impossible to determine the degree of 'equality' a treaty must possess, since the value of the obligations undertaken by subjects of international law is difficult to assess. And even if this were not so, a simple comparison of the duties imposed by a given treaty on one State with those incumbent on another State will not suffice, for the imbalance inherent in the treaty may be compensated by a reverse imbalance in another agreement" (supra note 1, p. 80).

${ }^{8}$ For deliberation of some of these classic points see Detter, supra note 1, pp. 1081-84.

${ }^{9}$ For a parallel account of how the idea of sovereign equality may 'qualify' the exercise of power see M. Byers, Custom, Power and the Power of Rules (OUP, Oxford, 1999) pp. 11-12.

${ }^{10}$ This idea reflects what McNair refers to as "forensic equality". A. McNair, "Equality in International Law', 26 Michigan Law Review (1927) p. 136. He quotes, in that regard, C. J. Marshall in The Antelope, 10 Wheat 66 ("[n]o Principle of general law is more universally acknowledged than the perfect equality of nations. Russia and Geneva have equal rights. It results from this equality that no one can rightfully impose a rule on another. Each legislates for itself, but its legislation can operate on itself alone.").

${ }^{11}$ On this see G. Simpson, Great Powers and Outlaw States: Unequal Sovereigns in the International Legal Order (CUP, Cambridge, 2004) pp. 25-61.
} 
The second form of response takes a somewhat different direction. The argument here is that the problem of unequal treaties has already been resolved, or pushed into the pre-modern past; for all their significance in the 19th Century, the eclipsing of colonialism and the prohibition on duress in the context of treaty-making are such as to have rendered obsolete the very term. ${ }^{12}$ The fact that international law now appears to be definitively set against the continuance (or reintroduction) of colonial relations ${ }^{13}$ appears to obviate recourse to an idea that was imprinted in the asymmetrical relations of power that characterised the colonial era in the 19th Century. The end of colonialism marks the end of ideas of oppression and resistance associated with it. ${ }^{14}$ As an emblem of this moment of change, the problem of unequal treaties also appears to have been directly addressed by means of the introduction, within the law of treaties, of a provision that effectively strips of validity those treaties procured by way of the unlawful use of force (Articles 51 and 52, Vienna Convention on the Law of Treaties, 1969). ${ }^{15}$ Since, it might be reasoned, the 19th Century 'unequal' treaties were procured by dint of coercion, and since duress is now regarded as vitiating the legitimacy of any agreement, the problem has been legislated away. ${ }^{16}$

${ }^{12}$ See e.g., Brownlie, supra note 5, p. 620.

${ }^{13}$ Legal Consequences for States of the Continued Presence of South Africa in Namibia (South West Africa) Notwithstanding Security Council Resolution 276 (1970) Advisory Opinion, ICJ Rep. 1971, 16; Western Sahara Case, Advisory Opinion, ICJ Rep. 1975, 12, paras. 54-59.

${ }^{14}$ Gong suggests that the 'modern' idea of unequal treaties regards it as an "integral part of 'imperialism' and 'colonialism",, (Gong, (supra note 6, pp. 66-67). Alexandrowicz also heralds the 20th Century as an era in which the suspect "positivism" of the 19th Century is overtaken by a return to the universalist creed of Grotius and Vattel. C. Alexandrowicz, An Introduction to the History of the Law of Nations in the East Indies (Clarendon Press, Oxford, 1967) pp. 10, 235.

${ }^{15}$ Article 51 reads:

"The expression of a State's consent to be bound by a treaty which has been procured by the coercion of its representative through acts or threats directed against him shall be without any legal effect."

Article 52 reads:

"A treaty is void if its conclusion has been procured by the threat or use of force in violation of the principles of international law embodied in the Charter of the United Nations."

${ }^{16}$ There seems to be no doubt, of course, that the prohibition on the unlawful use of armed force has the status of ius cogens, (Nicaragua (Merits) (1986) ICJ Rep. 14, p. 100) and Article 52 would seem to be a particularly self-evident expression of that idea. 
Both of these arguments would seem to displace the problem of unequal treaties in particular ways: the first by treating the problem as either unresolvable or dangerous (introducing instability and uncertainty into formal legal discourse), the second by treating it as already having been adequately addressed within the terms of international law. In fact, the points of difference are quite stark. The first appears to admit the continuance of inequality denied by the second. The second appears to assert the possibility of a legal response denied by the first. As a matter of consistency, it appears difficult to hold both positions: the problem of unequal treaties is either one incapable of remedy (because we have to assume that inequality is pervasive and enduring), or one that has already been remedied by the elimination of status discrimination and the prohibition on the use of force. That resort may be had, on occasions, to both arguments as a way of defending the current marginalisation of the issue is perhaps only reflective of an ambivalence as to whether international law has, or ever will be able to, shake off its colonial past.

Since the argument pursued here is less concerned with the question whether there is an obvious remedy, but rather with the prior issue as to whether or not the problem of unequal treaties is one to which we should continue to attend, two particular lines of thought inform the following discussion. The first concerns an engagement with the idea that the problem of inequality is something regarded as external to international legal discourse rather than something directly imprinted within it. At one level this may be cast in terms of the apparent internalisation within international legal discourse of the various divisions employed, from time to time, to describe international society - divisions between lawful and lawless States, between the 'successful' and the 'failed', between democratic and autocratic, between Great powers and the small and powerless. Here, a pluralist conception of international society is pitted against the various attempts to describe that society in terms of hierarchy. ${ }^{17}$ At another level, however, the problem of inequality also concerns the way in which a flattening of power relations within the framework of formal treaty rules may itself serve an ideological purpose: by casting concessions procured by dint of power in an egalitarian light and obscuring existing asymmetrical relations by reference to a fictitious notion of equality. After all, to argue that one cannot tell whether treaties are equal or unequal is only such as to put in question a prior issue as to their authority: it is only by way of assuming that they are, for the most part, responsive to mutual interests - that they are broadly equal or 'fair' in the broadest sense - that this can be maintained. If, by contrast, one were to assume that all (or the majority of) treaties were unilateral impositions, any

\footnotetext{
${ }^{17}$ See e.g., Simpson, supra note 11.
} 
argument that they were thereby obligatory upon both parties in virtue of a fictive 'consent' would be hard to sustain. ${ }^{18}$ Far from being a matter external to international law, the problem of inequality seems to cut to the heart of any commitment to it.

The second line of thought concerns the progressivist trajectory of international law, and its relationship with colonialism. In many accounts the 'era of colonialism' is equated with the formal assumption of sovereignty by European powers over non-European territories and peoples. The main point of critique, in that regard, being the passive acquiescence of international law in the process of empire building - through its toleration of annexation and denial of native sovereignty. According to many such accounts, the Charter era, and the accompanying process of decolonisation, brought colonialism as a practice to an end. The hierarchical ordering of international society that engendered the expansion of colonial empires was replaced by a commitment to formal equality; the continuance of colonial rule replaced by a commitment to the fostering of self-determination; the tolerance of forcible annexation replaced by a general prohibition on the use of force.

Such a rendering of the 'problem of colonialism', however, scarcely engages with the relationship between colonial practice and the imperial designations that supported it. Even if colonialism, as an idea, was associated with the establishment of colonial settlements or the assumption of formal rule over territories in Africa and Asia, it could by no means easily be separated from the broader discourse of Empire. As Said explains it, 'imperialism' represents "the practice, the theory, and the attitudes of a dominating metropolitan centre ruling a distant territory" for which 'colonialism', strictly concerned with the implanting of settlements on distant territories, is merely one of its (accidenta $1^{19}$ ) consequences. ${ }^{20} \mathrm{He}$ concludes that whilst "colonialism has largely ended . . . imperialism . . . lingers where it has always been, in a kind of general cultural sphere as well as in specific political, ideological,

18 E. Carr, The Twenty Years' Crisis 1919-1939: An Introduction to the Study of International Relations (Macmillan, 2nd ed., London, 1946) p. 174 ("it can be maintained with considerable show of reason that insistence on the legal validity of international treaties is a weapon used by the ruling nations to maintain their supremacy over weaker nations on whom the treaties have been imposed.").

${ }^{19}$ Cf. J. Seeley, The Expansion of England [1883] (Macmillan, London, 1931) p. 143 (The British acquisition of India "was made blindly. Nothing great that has every been done by Englishmen was done so unintentionally, so accidentally, as the conquest of India . . . in India we meant one thing, and did another".).

${ }^{20}$ E. Said, Culture and Imperialism (Random House, Random House, 1993) p. 8. The distinction between the practice of colonialism and imperialism as a 'driving force' largely stemmed from the moment in which the latter came to be associated, in the hands of Lenin and Hobson, with economic domination. 
economic, and social practices". ${ }^{21}$ Said's specific endeavour was to locate the continuance of an imperial ideology in the cultural frames of reference of Western art and literature - initially at the level of a textual 'discourse' that combined knowledge and power in the creation and domination of the 'Orient'. Whilst there is certainly an ambivalence in his work both as regards the orientation of such knowledge formations (to intentionally dominate?) and their representative function (does the Orient preexist the discourse?), ${ }^{22}$ it at least puts into frame the question whether certain disciplinary forms such as the notion of the treaty as a contractual bargain between sovereign equals - might serve some continuing imperial purpose.

Certainly if one is to think about the particular project of colonialism in terms of Western economic expansion (including the opening of new markets and investment opportunities), ${ }^{23}$ it is by no means obvious that one would take the view that formal decolonisation has brought to an end the practices that marked the imperial era. If, in that context, the colonial era may be taken to embrace not merely the formal relations of colonialism (the establishment of colonies), but also the dynamics of 'informal empire' as exercised through, amongst other things, an 'imperial policy of free trade', ${ }^{24}$ the problems of sovereignty or territorial title would seem to be less obviously problematic than the continuance of relations of dominance under the banner of an overt commitment to formal equality and self-determination. It is in the idea of informal empire, in other words, that a critique of colonialism might retain an enduring value for the current project of international law.

\section{Unequal Treaties and Informal Empire}

The problem of unequal treaties as it was to arise in the 19th Century was primarily associated with the establishment of a series of treaty regimes between a number of Western powers on the one hand and a handful of States

${ }^{21}$ Ibid.

${ }^{22}$ See R. Young, Postcolonialism: An Historical Introduction (Blackwell, Oxford, 2001) pp. 390-1.

${ }^{23}$ For the view that imperialism may be understood as a "largely economic rather than largely territorial enterprise”, see G. Spivak, A Critique of Postcolonial Reason: Toward a History of the Vanishing Present (Harvard University Press, Cambridge, Mass, 1999) p. 3.

${ }^{24}$ See J. Gallagher and R. Robinson, 'The Imperialism of Free Trade', 6 Economic History Review (1953) 1. This thesis prompted a lively academic debate as regards the accuracy of their characterisation of mid-Victorian policy as regards free trade. See e.g., O. MacDonagh, 'The Anti-Imperialism of Free Trade', 14 Economic History Review (1962) p. 489; R. Moore, 'Imperialism and "Free Trade" Policy in India, 1853-4', 17 Economic History Review (1964) p. 135; D. Platt, 'The Imperialism of Free Trade: Some Reservations', 21 Economic History 
in East Asia including Japan, ${ }^{25} \mathrm{Siam}^{26}$ and $\mathrm{China}^{27}$ on the other. The agreements in question were all remarkably similar. They all provided for the opening of specified seaports to foreign trade; ${ }^{28}$ they all established a system of extraterritorial jurisdiction (in which all nationals of the foreign powers were granted immunity from local jurisdiction, and were subordinated instead to the jurisdiction of the local consul); they all fixed import duties at a specified level. ${ }^{29}$ For the most part, the treaties also included most-favoured

Review (1968) p. 296; B. Semmel, The Rise of Free Trade Imperialism (1970); P. Cain and A. Hopkins, British Imperialism: Innovation and Expansion, 1688-1914 (Longmans, London, 1993) pp. 8-10.

${ }^{25}$ In the case of Japan, the main Treaties in question were those concluded as between the US, Netherlands, Russia, Great Britain and France in 1858, (JFO Treaties, 727, 512, 589, 418 and 291) supplemented by the Tariff Convention of 1866 (JFO Treaties, 321), and the subsequent agreements with Prussia in 1861 (JFO Treaties, 367), Switzerland in 1864 (17 Martens NRG, II, p. 42), Belgium in 1866 (id. at 51), Italy (id. at 61), Denmark in 1867, Portugal (id. at 21), Sweden-Norway in 1868, Spain in 1868 (17 Martens NRG, II, p. 89); North German Confederation in 1869 (19 Martens, NRG, II, 435) and Austria-Hungary in 1869 (20 Martens, NRG, II, 418). See generally, S. Murase, 'The Most Favoured-Nation Treatment in Japan's Treaty Practice during the Period 1854-1905', 70 American Journal of International Law (1976) p. 280; T. Takeuchi, War and Diplomacy in the Japanese Empire (Allen and Unwin, London, 1935).

${ }^{26}$ In case of Siam, the main treaties are the 'Bowring Treaty' concluded with Britain in 1855 (46 BFSP 138) and those subsequently concluded with US, France and Denmark in 1856, with Portugal in 1859, the Netherlands in 1860, with Germany in 1862, with Sweden and Norway, Belgium and Italy in 1868 with Austria-Hungary in 1869, and with Spain in 1870. See generally, Gong, (supra note 6) pp. 201-237; S. Sucharitkul, 'Asian Perspectives of the Evolution of International Law: Thailand's Experience at the Threshold of the Third Millenium', 1 Chinese Journal of International Law (2002) p. 527; E. James 'Jurisdiction over Foreigners in Siam', 16 American Journal of International Law (1922) p. 590; F. Sayre, 'The Passing of Extraterritoriality in Siam', 22 American Journal of International Law (1928) 70.

${ }^{27}$ In case of China, the principal agreements were the Treaties of Nanking (1842) and Tientsin (1858) with Britain (Hertslet's China Treaties (HMSO, London, 1908) I, No. 1, p. 7; No. 6, p. 18); the Treaty of Shanghai (1861) with Germany (Ibid. No. 56, p. 331); the Treaty of Tientsin (1858) with Russia (ibid. No. 81, p. 455); and the infamous Boxer Protocol of 1901 concluded with Germany, Austria-Hungary, Belgium, Spain, the USA, France, Britain, Italy, Japan, the Netherlands and Russia (ibid, No. 26, p. 123). See generally, W. Tieya, 'International Law in China: Historical and Contemporary Perspectives', 195 Hague Recueil (1990) p. 232.

${ }^{28}$ For the rights of foreign powers in the port areas see Willoughby, Foreign Rights and Interests in China (Johns Hopkins, Baltimore, 1927) I, pp. 500-3; Q. Wright, Legal Problems in the Far Eastern Conflict (AMS Press, New York, 1941) pp. 69-73.

${ }^{29}$ In the case of Japan four classes of duty were imposed ranging from zero (gold, silver, furniture and books), to 35 per cent (intoxicating liquor). Most imports were treated as Class 2 for which a duty of 5 per cent was payable (this included foodstuffs, coal, timber, machinery, silk, cotton and woollen goods, and certain metals). In case of China a flat rate of 5 per cent was payable on all imports, and in case of Siam, the duty was locked at 3 per cent. 
nations (MFN) clauses extending the benefits accrued by any one State to all others, ${ }^{30}$ and were imposed without time limit, providing only occasionally for their revision. In addition, the agreements frequently contained provisions governing the granting of concessions to foreign enterprises in the field of mining, railways and shipping, for freedom of navigation in inland waters, and for the protection of Christian missionaries. In some cases, furthermore, they provided for the cession or lease of territory to foreign powers. ${ }^{31}$

These agreements were by no means unique in all their terms. They were foreshadowed both as regards the inclusion of MFN clauses and the provision of extraterritorial and consular jurisdiction by the capitulation treaties with the Ottoman Empire in the 17th Century, and similar provisions were also to be found in treaties elsewhere in North Africa and Asia. ${ }^{32}$ What was unusual, however, was the overtly non-reciprocal nature of the arrangements, their scale in terms of the number of parties involved, and the apparent willingness of the Western Powers to act in concert. ${ }^{33}$ More significant than this, however, is the fact that the treaties themselves became a central focal point for the development of nationalist sympathies within China, Japan and Siam leading, in the case of the former, to the overthrow of the incumbent government (the Qing dynasty). The treaties were also highly influential, as it turned out, as regards the fostering of legal and institutional reform in all three countries.

\footnotetext{
${ }^{30}$ The existence of MFN clauses made renegotiation particularly difficult. See Murase, supra note 25. Thus, when the Chinese American Treaty of 27th July 1928 was signed annulling the terms of earlier treaties restricting import and export tariffs, it was dismissed by Japan as an "empty gesture" and a "mean trick". See W. Dennis, 'The Treaty Regulating Tariff Relations between the United States and China', 22 American Journal of International Law (1928) p. 834.

${ }^{31}$ E.g., Hong Kong and part of Kowloon ceded from China to Britain, Macau to Portugal and Cochin to France. A number of Chinese territories were also "leased" by Western powers including Kiaochow, Port Arthur, Kowloon, Kwangchouwan, and Weiheiwei. In the cases of Siam, Kelantan, Trengganu, Kedah, Perlis and adjacent islands were ceded to Britain under the Treaty of Bangkok of 1909, and portions of territory to France under the Franco-Siamese Treaty of 1907.

${ }^{32}$ See generally, Alexandrowicz, supra note 14; C. Alexandrowicz, 'Treaty and Diplomatic Relations between European and South Asian Powers in the Seventeenth and Eighteenth Centuries', 100 Hague Recueil (1960) p. 203; H. Kassan, 'Extraterritorial Jurisdiction in the Ancient World', 29 American Journal of International Law (1935) p. 237.

${ }^{33}$ Although the original 'open door' policy gave way in the late 19th Century to a scramble for concessions, European nations frequently presented a common front. This was particularly apparent in the unique example of collective military intervention by European powers to put down the Boxer Rising of 1900, which Wight suggests "might be taken as the dramatic beginning of the contemporary phase of international history". M. Wight, Power Politics (1978) p. 57. For an account of the negotiations following the Boxer Rising see, W. Manning, 'China and the Powers Since the Boxer Movement', 4 American Journal of International Law (1910) p. 848 .
} 
It is apparent that the overt intention lying behind these agreements was never one of imperial annexation. Although in several cases parts of the territory of China and Siam were ceded, or leased to Western Powers, and whilst Western powers frequently exercised control over certain areas of territory, ${ }^{34}$ the dominant political ethos in Western Europe the middle of the 19th Century was largely opposed to the expansion of formal colonial possessions embracing, in its stead, the ideal of free trade. ${ }^{35}$ These treaties, in fact, seemed to encapsulate that ideal: their aims being broadly concerned with the elimination of historic impediments to trade such as local monopolies or restrictions upon access; the provision of a stable environment in which traders might operate, by way of excluding the jurisdiction of local courts; and the elimination of protectionist tariffs and practices that restricted foreign imports. There was, furthermore, an initial reluctance on the part of Western powers to do more than secure channels for trade ${ }^{36}$ even if, by the late 19th Century, this had drifted towards the creation of 'spheres of influence'.

Despite their overt concern with 'trade not rule', it is apparent that the relations brought into play by means of the treaties in question were coloured with precisely the same rhetorical flourishes that served to substantiate later colonial annexations. The regimes themselves were, at the outset, procured overtly on the basis of projected cultural images of the Orient and the Oriental. It was not merely the existence of protectionist policies, or a reluctance to open their doors to trade, that were the cause of concern. Rather, it

\footnotetext{
${ }^{34}$ Under an agreement between the British consul and the Chinese authorities in 1845 a foreign settlement with self-governing administrative power was established in Shanghai. By 1914 eight nations including Britain, the US, Japan, France and Russia had established such settlements in thirteen cities. In case of Siam, Britain and France partitioned their respective zones of influence in the Declaration of London 1885.

${ }^{35}$ In Britain, Cobden, Bright and the economists of the Manchester School rallied round the idea that colonialism was economically burdensome and that the Empire should therefore be disbanded. They argued, rather, for the ending of colonial preferences and the advancement of free trade. This led Lenin, amongst others, to the conclusion that 'imperialism' only really gained momentum from the period of colonial rivalry from 1860 onwards, V. Lenin, Imperialism, the Highest Stage of Capitalism (Selected Works, nd). V ("When free competition in Great Britain was at its height, i.e. between 1940 and 1860, the leading British bourgeois politicians were . . of the opinion that the liberation of the colonies and their complete separation from Great Britain was inevitable and desirable.") Such ideas also evidently informed diplomacy. In the negotiation of the Treaty of Tientsin, for example, Lord Elgin was instructed to bear in mind throughout negotiations that "Her Majesty's Government have no desire to obtain any exclusive advantages for British trade in China, but are only desirous to share with all other nations any benefits which they may acquire in the first instance specifically for British commerce." Quoted by A. Sargent, Anglo-Chinese Commerce and Diplomacy (Clarendon Press, Oxford, 1907) p. 109.

${ }^{36}$ See Cain and Hopkins, supra note 24, pp. 360-380.
} 
was the 'backward' and capricious nature of their legal and administrative systems - the use of torture in the criminal justice systems, the imposition of group responsibility, and the corruption in administration ${ }^{37}$ - that warranted the imposition of extraterritorial arrangements. ${ }^{38}$

In its most modest form, this came to be expressed in terms of a cultural incompatibility. As the US Government later came to explain the situation in a note of 1929:

"The exercise by the United States of jurisdiction over its citizens in China had its genesis in an early agreement that, because of differences between the customs of the two countries and peoples and differences between their judicial systems, it would be wise to place upon the American Government the duty of extending to American nationals in China the restraints and benefits of a system of jurisprudence to which they and their fellow nationals were accustomed in the United States". ${ }^{39}$

For those adhering to such a position, the exercise of extraterritorial jurisdiction was in no sense an imperial strategy or one motivated by a sense of cultural superiority. ${ }^{40}$ Rather, it was rooted in a sense of historical disconnectedness, and elaborated on the basis of the simple fact of economic, social, cultural, or political specificity: the Chinese, Japanese and Siamese were simply different, no more, no less. ${ }^{41}$

${ }^{37}$ See on this, H. Morse, International Relations of the Chinese Empire (Longmans, London, 1910) I, pp. 95-117.

38 See generally, B. Williams, 'The Protection of American Citizens in China: Extraterritoriality', 16 American Journal of International Law (1922) p. 43; R. Gilbert, The Unequal Treaties, China and the Foreigner (Murray, London, 1929); Denby, supra note 6, pp. 669-70; H. Quigley, 'Extraterritoriality in China', 20 American Journal of International Law (1926) pp. 50-51.

${ }^{39}$ American Reply to Chinese Note to the Six Powers Concerning the Abolition of Extraterritoriality, 10 August 1929 (J. Murray), in Woodhead, supra note 6, p. 63.

${ }^{40}$ As Keeton was to put it, extraterritoriality far from being "repugnant to the best traditions of international intercourse" was in fact "the accepted method of entering into treaty-relations with an Eastern Power whose jurisdiction is not so far developed that it can be recognized by Western States". Keeton, supra note 6, pp. 126-7.

${ }^{41}$ Several authors in the early 20th Century took great pains to point out that extraterritoriality was not a 19th Century invention, but rather something that characterised relations in the pre-modern era, and which had largely been overcome by a cultural assimilation. E.g., A. Putney, 'The Termination of Unequal Treaties', 21 American Society of International Law Proceedings (1927) p. 87; E. Pears, 'Turkish Capitulations and the Status of British and Other Foreign Subjects Residing in Turkey', 21 Law Quarterly Review (1905) p. 408; L. Thayer, 'The Capitulations of the Ottoman Empire and the Question of their Abrogation as it Affects the United States', 17 American Journal of International Law (1923) pp. 207-215. 
Of course, this liberal idea of toleration of difference never explained why extraterritoriality was imposed on a non-reciprocal basis, why limited recourse was had to mixed courts in cases of disputes involving Chinese or Japanese nationals, or why the Western nations eventually extended consular jurisdiction in the mixed court in Shanghai to deal with disputes in which no foreign national was involved. ${ }^{42}$ Nor did it explain the establishment of international settlements, or the controls over tariffs, or the direct involvement of the British in the collection of customs dues in China. Over and above a desire to guarantee respect for cultural difference, the treaties seemed designed not only to procure commercial advantage for Western trade - preserving in the process 'zones of civility' within the Orient - but also to lay the groundwork for the tutelage of these 'backward' countries into the self-evident advantages of enlightened Western law and governance. ${ }^{43}$

As Said observes, the elaboration of a cultural divide between East and West in 19th Century thought, served two clear purposes. On the one hand it provided a basis for justifying imperial practices in relation to the 'Orient', ${ }^{44}$ - in this case the imposition of extraterritorial and other arrangements upon powers in East Asia. On the other, it operated recursively to validate the West's sense of its own cultural superiority. The cultural distinctiveness of the East Asian States, as far as Western international lawyers were concerned, therefore, not only reinforced the belief that international law had its genesis in a specifically European tradition, but also encouraged the notion that it was only by emulating Western modes of governance (and Western understandings of the law of nations) that polities on the periphery might be admitted

\footnotetext{
${ }^{42}$ For an account of the mixed-court in Shanghai see Willoughby, supra note 6, pp. 62-4; Quigley, supra note 38, pp. 55-57; S. Barton, 'The Shanghai Mixed Court', 5 Chinese Social and Political Science Review (1920) p. 31; M. Hudson, 'Rendition of the International Mixed Court in Shanghai', 21 American Journal of International Law (1927) p. 451.

${ }^{43}$ See e.g., J. Fairbank, China Perceived: Images and Politics in Chinese-American Relations (London, Deutsch, 1976) p. 86. (The treaty regimes represented "a semipermanent form of Western intervention in Chinese life . . . an East Asian wing of Europe's worldwide hegemony, specially an arm of British informal empire"); J. Osterhammel, 'SemiColonialism and Informal Empire in Twentieth-Century China: Towards a Framework of Analysis', in W. Mommsen and J. Osterhammel (eds.), Imperialism and After: Continuities and Discontinuities (Allen and Unwin, London, 1986) p. 290 (As an extension of 'informal empire' the treaty regimes enabled colonial powers to maintain a 'business system' in 'semicolonial' China).

${ }^{44}$ Said's observation that " $[\mathrm{t}]$ he Orient was Orientalized not only because it was discovered to be 'Oriental' in all those ways considered common-place by an average nineteenth-century European, but also because it could be ... made Oriental”' has particular salience here. E. Said, Orientalism (Routlege and Keegan Paul, London, 1979) pp. 5-6.
} 
into the family of nations. In many cases it was through the medium of extraterritorial agreements that this was to be enabled. ${ }^{45}$

It was significant, in that sense, that whilst the early treaties in question did not provide for revision or unilateral termination, the arrangements in general came to be understood as reviewable only once requisite reforms of local law and administration had taken place. This was, de facto, the case as regards the Japanese renegotiation of the treaty arrangements in 1897, and the relaxation of the regimes in Siam, ${ }^{46}$ but was very much more explicit in diplomatic negotiations with China. In the case of several treaties concluded with China in 1902-3 the reform of Chinese law became a prerequisite for any renunciation of rights of extraterritoriality. ${ }^{47}$ This later became a more general policy (for those States that had not been forced to abdicate extraterritorial rights in $\mathrm{China}^{48}$ ) following the Washington Conference of 1922 which mandated the appointment of a Commission appointed for purposes of fact-finding in this respect. ${ }^{49}$ Even though the Commission was unable to

\footnotetext{
${ }^{45}$ Wheaton observes in 1880 with some satisfaction that, as a consequence of its engagements with the West, China "has been compelled to abandon its inveterate anti-commercial and anti-social principles, and to acknowledge the independence and equality of other nations in the mutual intercourse of war and peace". (H. Wheaton, Elements of International Law (Boyd A. Stevens and Sons, 2nd ed., London, 1880) p. 20).

${ }^{46}$ Britain terminated the regime of extraterritoriality in Siam in 1909. The US agreed to relinquish the regime in 1920 subject to the right of revocation until five years after the Siamese modern codes had come into force.

${ }^{47}$ Article 12 of the Sino-British Commercial Treaty of 1902. Chinese Customs Treaties, I, 557; Article 15 of the Commercial Treaty of 1903 between China and the US, Ibid, 756; Article 11 of the Commercial Treaty of 1903 between China and Japan, Ibid, II, p. 662.

${ }^{48}$ Austria and Hungary were forced to renounce their rights under the terms of the Peace Treaties of St Germain (Articles 113-117) and Trianon (Articles 113-117) in 1919. China refused to sign the Versailles Treaty because Germany's rights relating to Shantung were ceded to Japan under Articles 156-158, but Germany confirmed its renunciation of extraterritorial rights in Articles 128-134 of the bilateral agreements with China of 20 May 1921.

${ }^{49}$ In that conference, eight powers - US, Belgium, Britain, France, Italy, Japan, the Netherlands, and Portugal - resolved to relinquish extraterritoriality as soon as appropriate reforms had been made in the law of China. The nine power treaty that resulted proclaimed respect for the independence and territorial integrity of China, asserted the Open Door policy, and abandoned the pre-war competition for concessions. The Commission, for its part, was instructed to:
}

\footnotetext{
"enquire into the present practice of extra-territorial jurisdiction in China, with a view to reporting to the Governments of the several Powers . . their findings of fact in regard to these matters and their recommendations as to such means as they may find suitable to improve existing conditions of the administration of justice in China, and to assist and further the efforts of the Chinese Government to effect such legislation and judicial reforms as would warrant the several Powers in relinquishing either progressively or otherwise their respective rights of extra-territoriality."
} 
recommend the immediate relinquishment of extra-territoriality in $1926^{50}$ many of the arrangements in question were renegotiated by the end of that decade - the regime finally being brought to a close with the agreement of Britain and the United States in $1943 .{ }^{51}$ By this time many of the defects of the regimes of extraterritoriality had become fully apparent ${ }^{52}$ and commentators were almost universal in the view that extraterritoriality and consular jurisdiction could not be maintained indefinitely. ${ }^{53}$ Their abandonment, however, appears to have been precipitated primarily by reason of the Japanese intervention in China. ${ }^{54}$

${ }^{50}$ Report, Part IV. See Summary and Recommendations of the Report of the Commission on Extraterritoriality in China, 1926, 21 American Journal of International Law, Supplement (1927) p. 58.

${ }^{51}$ See generally, Q. Wright, 'The End of Extraterritoriality in China', 37 American Journal of International Law (1945) p. 286.

${ }^{52}$ Among the 'anomalies' listed by the Commission in the practice of extraterritoriality were: the multiplicity of courts and the diversity of laws involved; that the extra-territorial court had no jurisdiction over an alien plaintiff or witness; that defendants were debarred from bringing counterclaims against aliens; that several courts of several nationalities become involved when aliens of different nationalities were joined in the same case; the inaccessibility of the extraterritorial courts; lack of training of consular judges; that appeals in many cases could only be heard in the State of nationality; that foreign nationals were generally exempt from enforcement of Chinese legislation concerning traffic, taxation and the press; that disputes arose as to the nationality of persons in question; and that premises occupied by foreigners had become places of refuge for Chinese wanted by Chinese Courts. Supra note 50, p. 60.

${ }^{53}$ For those questioning the value of extraterritorial jurisdiction and consular authority in the 20th Century see F. Hinckley, 'Consular Authority in China by New Treaty' 21 American Society International Law Proceedings (1927) p. 82; M. Tyau, 'Extraterritoriality in China and the Question of its Abolition', 2 British Yearbook of International Law (1921-22) p. 133; Sayre, supra, note 26, p. 73; Willoughby, supra, note 6, pp. 114-20; Quigley, supra, note 38, pp. 57-60. As Martti Koskenniemi points out, however, (The Gentle Civilizer of Nations: The Rise and Fall of International Law 1870-1960 (Cambridge, Cambridge University Press, (2002) p. 135) "everything depended upon ... the degree to which aspirant communities were ready to play by European rules. But the more eagerly the non-Europeans wished to prove that they played by European rules, the more suspect they became ....".

${ }^{54}$ Whilst Secretary of State Hull declared, in 1943, that the ending of extraterritoriality was "a concrete exemplification of the high principles for which he United Nations are fighting", it was also apparent that the continuation of extraterritorial regimes made little sense in the context of Japanese occupation. See generally, K. Chan, 'The Abrogation of British Extraterritoriality in China 1942-43: A Study of Anglo-American-Chinese Relations', 11 Modern Asian Studies (1977) p. 257; Fishel, supra note 6, pp. 207-215; A. Thönnes, 'Das Ende der ungleichen Verträge in China', 4 Archiv des Völkerrechts (1953/54) 158. Significantly, for example, the United States had protested at the intent on the part of Japan to conclude an agreement with China in 1915 with the effect of conferring extensive rights upon Japan in Shantung, South Manchuria and Eastern Inner Mongolia. In the ensuing diplomatic exchange the United States had indicated that "it cannot recognize any agreement or undertaking which 


\section{The Charge of Inequality}

From an early stage, Western powers were faced with claims that the treaties in question were essentially unequal. Such claims were to persist for almost the entire life of the extraterritorial regimes becoming, at certain points in time, a significant focus for nationalist opposition to Western intervention. ${ }^{55}$ Whilst there has always been a tendency on the part of commentators to construe the demands in this respect in a narrow manner - to confine the sense of what was being demanded within a framework of more familiar concepts ${ }^{56}$ the demands appear to have been expressive of several different concerns. First of all, the claim to inequality was found in the fact that the agreements essentially cemented a permanent relationship of inferiority - more precisely a limitation on their territorial sovereignty by reason of the establishment of realms of extraterritorial jurisdiction and controls over tariff arrangements. There was no doubt, after all, that the notion of territorial sovereignty was understood as implying the right to exclusive jurisdiction over persons and property within

has been entered into or which may be entered into between the Governments of China and Japan impairing the treaty rights of the United States and its citizens in China, the political or territorial integrity of the Republic of China, or the international policy relative to China commonly known as the Open Door Policy."

55 The revision of unequal treaties was to become a major political platform for the Nationalist government in China. In July 1928 the Ministry of Foreign Affairs of the Nationalist Government published a statement to the effect that:

"While they will continue to afford protection to foreign lives and property in China according to law, the Nationalist Government hereby make the following specific declaration with regard to all unequal treaties:

All unequal treaties between the Republic of China and other countries which have already expired shall ipso facto be abrogated and new treaties shall be concluded.

The Nationalist Government will immediately take steps to terminate, in accordance with proper procedure, those unequal treaties which have not yet expired, and conclude new treaties.

In the case of the old treaties which have already expired but have not yet been replaced by new treaties, the Nationalist Government will promulgate appropriate regulations to meet the exigencies of the situation."

Chinese S., and P.S.R., July 1928, P.D. Supp., pp. 48-9. See generally, E. Fung, 'The Chinese Nationalists and the Unequal Treaties 1924-1931', 21 Modern Asian Studies (1987) p. 793.

${ }^{56}$ Caflisch, for example, interprets the Chinese opposition to unequal treaties as one in which inequality "was to be appreciated in terms of substance rather than appearance, i.e. by examining the intrinsic value of the parties' mutual obligations" (supra note 1, p. 61). 
the territory of a State,${ }^{57}$ and that exceptions to this basic precept - particularly where emanating from non-consensual processes - necessarily brought into question the status of the territory in question. ${ }^{58}$ If a State did not enjoy exclusive territorial jurisdiction, could it still be regarded as 'sovereign'?

The second concern was that the agreements had been procured by dint of coercion - that they had not been freely consented to, and reflected rather the presence of coercion and the inequalities in bargaining positions of the parties at the time of their conclusion. In the case of China, several treaties had been procured directly as a consequence of coercion. This was the case as regards the agreements with Britain, France and the United States had followed the Opium War in 1842, those with France after the Franco-Chinese war of 1884, and that with Japan following the Chinese-Japanese War of 1894-5. Several others were concluded in the aftermath of European intervention in China to repress the Tai-ping rebellion (1850-64) and the Boxer uprising in 1900-2. In case of Japan and Siam, coercion was less overt, but no less apparent to the local administration. A number of agreements were concluded in the aftermath of the Opium Wars - the mere symbol of which was sufficient to persuade neighbouring countries that resistance was likely to be futile ${ }^{59}$ - and were frequently bolstered by the presence of warships ${ }^{60}{ }^{60}$ The occasional bombardment of ports (in Japan 1863 and 1865) only reinforced the point.

Finally, inequality was evident in the essentially non-reciprocal nature of the agreements: which conferred nearly all rights upon the Western powers and imposed all corresponding duties upon the other party. Some treaties, such as those between China and the United States (1844), Britain (1876)

\footnotetext{
${ }^{57}$ Wheaton, supra note 45, p. 111 ("As a corollary to the proposition that every State is entitled to exercise exclusive sovereignty and jurisdiction throughout its territory, no State is entitled to control persons beyond its own territory").

${ }^{58}$ Cf. T. Baty, 'Protectorates and Mandates', 2 British Yearbook of International Law (1921-22) p. 109, p. 112 (commenting that African and Asian peoples "could neither be ignored as States nor treated quite on the footing of ordinary States").

${ }^{59}$ The Harris agreement of 1858 - which later formed the model for subsequent agreements was deliberately negotiated on the basis that if nothing were to be conceded, Britain was willing to have recourse to force of arms. T. Harris, The Complete Journal of Townsend Harris: First American Consul and Minister to Japan (1804-1878) (M. Cosenza ed., Rutland, Tuttle, 1959), pp. 485-6.

${ }^{60}$ The threat was such that in one case - the agreement of 14 October 1854 with Britain was offered by Japan to Rear Admiral James Stirling in the mistaken belief that his squadron had arrived in Nagasaki for that purpose. The real intention, apparently, was to seek Japanese neutrality in the war with Russia. See W. Beasley, 'The Foreign Threat and the Opening of the Ports' in J. Hall et al. (eds.), The Cambridge History of Japan, (Cambridge University Press, Cambridge, 1989) V, 259, p. 271.
} 
and Norway, (1847) were entirely non-reciprocal. In others, some modicum of reciprocity recognised, such as the admission of consuls, but such provisions were remarkably rare. None of the agreements in question provided for reciprocal consular jurisdiction or rights of extraterritoriality. ${ }^{61}$

The charge of inequality, therefore, was essentially associated with three quite distinct ${ }^{62}$ elements of the relationship: the first concerning the status of the parties, the second the context surrounding the conclusion of the agreements, and the third, the content and form of the agreement itself. All three of these raised specific questions for international lawyers that seemed to fall, broadly speaking, under the headings: the problem of sovereignty, the problem of power and coercion, and the problem of reciprocity.

\subsection{Status, and the Problem of Sovereignty}

In some respects, the problem of sovereignty was not as acute in the cases of China, Japan or Siam as it was later to become in the encounter between European Powers and African rulers. ${ }^{63}$ For the West, the problem was not one of seeking to justify their acquisition of sovereignty over territory in the periphery, or of dealing with the problematic relationship between conventional title and effective occupation. Rather, it was a case of seeking to secure a range of rights and privileges in relation to polities whose existence and influence as independent political communities was in some respects already self evident. Nevertheless, this brought with it, its own problems. Admitting that the polities in question were 'sovereign' seemed to be an indispensable condition for purposes of insisting upon the honouring of the treaty arrangements. ${ }^{64}$ Yet, at the same time, the terms of those agreements appeared to reflect a belief that the polities in question were somehow 'less than sovereign', and certainly less than equal.

${ }^{61}$ For a similar claim being raised in relation to Turkish capitulations see, Turkey No. 1, 1923, Lausanne Conference on Near Eastern Affairs, pp. 478-9, Foreign Relations (1914) p. 1092.

${ }^{62}$ There is no reason to suppose that all three elements should be present in any one case: not all treaties concluded by force are necessarily oppressive and not all treaties imposing unequal obligations are necessarily procured by force.

${ }^{63}$ On this see A. Anghie, 'Finding the Peripheries: Sovereignty and Colonialism in Nineteenth-Century International Law', 40 Harvard Journal of International Law (1999) p. 3; Koskenniemi, supra note 53, pp. 98-178.

${ }^{64}$ This may not have been a significant concern for international lawyers in the first half of the 19th Century who were happy to understand the compulsion deriving from treaty obligations in moral or political terms. See A. Carty, The Decay of International Law (Manchester University Press, Manchester, 1986) pp. 65-78. 
By the time of the treaty of Nanking of 1842, Western powers had already an extensive history of treaty-making in relation to Asian States dating back to the 16th Century - many of which were recorded in the annals of Ompteda and de Martens. ${ }^{65}$ In the case of China, this included the Treaty of Peace between China and Russia of 1689 (Nipchu) and the supplementary Treaty between the same of 1727 (Kiachta). Such relations were, for the most part, regarded as part and parcel of a universal law of nations - there being no question as to the capacity of the powers in question to conclude agreements, or as to their duty to honour them. ${ }^{66}$ It was only with the emergence of, what authors such as Alexandrowicz ${ }^{67}$ and Anghie ${ }^{68}$ have termed 'positive international law' in the 19th Century, that the question of status began to arise. ${ }^{69} \mathrm{By}$ the late 19th Century, the deductive rationalism of natural law and abstract rights (which had continued to find some recognition in the work of those such as de Martens, ${ }^{70}$ Klüber $^{71}$ and Phillimore, ${ }^{72}$ ) had given way to an emphasis

${ }^{65}$ See C. Alexandrowicz, 'Doctrinal Aspects of the Universality of the Law of Nations', 37 British Yearbook of International Law (1961) p. 506.

${ }^{66}$ D. Kennedy, 'International Law and the Nineteenth Century: History of an Illusion', 17 Quinnipiac Law Review (1997) p. 123, or 65 Nordic Journal of International Law (1996) pp. 406-407 (In the early nineteenth century "[s]overeigns came in a variety of shapes and sizes. Their powers and rights differed ... Sovereigns sometimes exercised sovereignty in their private or personal capacity and sometimes as public actors. They had sovereign rights in both capacities, but not yet a single, absolute authority in two different spheres. This was not yet the relative sovereignty of the twentieth century, disaggregated into a bundle of rights to be parcelled out among various actors. Nor was it yet the unified sovereignty of the turn of the century, which could be exercised in parts in a world of sovereigns and 'half sovereigns'. It was a sovereignty which had not yet been consolidated and which described the capacity and powers of a variety of actors.").

${ }^{67}$ Alexandrowicz, supra note 65, p. 514. ("The legal principles of universal relations, much as they had a reality of their own, were therefore gradually shifted to a second, more and more insignificant, plane; and this leads to the conclusion that the re-universalisation of the law of nations could only have taken place by positivist ways and means, i.e. by the admission of extra-European State entities to the European positive society").

${ }^{68}$ Anghie clearly relates the emergence of what he calls "sovereignty doctrine" to the encounter between the European and non-European world: "sovereignty doctrine emerges through . . . attempts to address the problem of difference". A. Anghie, "Francisco de Vitoria and the Colonial Origins of International Law', in E. Darian-Smith and P. Fitzpatrick (eds.), Laws of the Postcolonial (University of Michigan Press, Ann Arbor, 1999) p. 990.

${ }^{69}$ Kennedy describes this species of legal positivism as "simply the working out of the private law metaphor of contract applied to a public legal order". Kennedy, supra note 66, p. 113.

${ }^{70}$ G. de Martens, Précis du droit des gens moderne de l'Europe (Guillaume, 2nd ed., Paris, 1864).

${ }^{71}$ J. Klüber Europaishes Völkerrecht (Hurter, 2nd ed., Schotthausen, 1851).

${ }^{72}$ R. Phillimore, Commentaries upon International Law (Butterworths, 3rd ed., London, 1889) I, pp. 216-7; II, pp. 45-6. 
upon diplomatic practice rooted within culture and history as the dominant mode of explanatory discourse. ${ }^{73}$ Suddenly, international law was no longer a cosmopolitan venture - one whose geographical boundaries were open but one imprinted in the traditions and values of an unapologetically Christian Europe. ${ }^{74}$ Despite the history, the treaties, and the diplomatic missions, relations with the Orient (China, Japan, and the Ottoman Empire, in particular) came under fresh scrutiny: could these States rightly be regarded as subjects of international law? Was there sufficient cultural or religious affinity with the basic precepts of international law to warrant their inclusion within 'the family of nations'? ${ }^{75}$

In the case of China, in particular, this seemed to present a rather special set of problems. Europeans had been made vaguely aware, in the early 19th Century, of the essentials of the tributary system that underpinned Chinese 'foreign' policy. ${ }^{76}$ They were scandalised to learn that, according to that system, those who had not embraced the Chinese way of life (i.e. foreigners) were regarded as barbarians - their presence tolerated only insofar as they were seen to pay

${ }^{73}$ As Koskenniemi argues that "the founding conception of late nineteenth-century international law was not sovereignty but a collective (European) conscience - understood always as ambivalently consciousness or conscience, that is, in alternatively rationalistic or ethical ways" (supra, note 53, p. 51). This was already evident in Kluber's and de Martens' description of international law as a law of 'Europe', and became cemented in the idea that the rules of international law were a "reflection of the moral development and the external life of the nations which are governed by them" (Hall, A Treatise on International Law (Clarendon Press, 4th ed., Oxford, 1895) p. 1).

${ }^{74}$ For Wheaton (supra note 45, pp. 15-16) the question was whether there was a "uniform law of nations". Whilst his answer was in the negative he did stress that "the public law ... has always been, and still is, limited to the civilized and Christian people of Europe and to those of European origin". By the early 20th Century, this limited pluralist position had been modified. Lawrence remarks, in that vein, that " $[\mathrm{t}]$ he area in which the law of nations operates is supposed to coincide with the area of civilisation. To be received within it is to obtain a kind of international testimonial of good conduct and respectability". (T. Lawrence, The Principles of International Law (Macmillan, 3rd ed., London, 1905) p. 59).

${ }^{75}$ One of the first projects of the Institut de Droit International was to examine whether States within the Orient could be regarded as having a common understanding of international law. The conclusion drawn by Sir Travers Twiss was that they did, at least, have a sufficient understanding of the notion pacta sunt servanda. Sir Travers Twiss, 'Rapport', 3-4 Annuaire Institut de Droit International (1879-1880) p. 301. Concluding that there was not much more to be said about the issue - however complicated it seemed - the Insititut proceeded to move on to deal with problems associated with consular jurisdiction and extraterritoriality. See generally, Koskenniemi, supra note 53, pp. 132-6.

${ }^{76}$ See generally, J. Fairbank and S. Têng, 'On the Ch'ing Tributary System', 6 Harvard Journal of Asiatic Studies (1941) p. 135; J. Fairbank 'Tributary Trade and China's Relations with the West', 1(2) The Far Eastern Quarterly (1942) p. 129. 
tribute to the Emperor, the Son of Heaven. ${ }^{77}$ This was to become a point of some significance for Western Powers. In his instructions to the British Plenipotentiary in the 1840 s, Palmerston was to make respect for the equal dignity of the British envoy a sine qua non of any agreement with China. Thus, in Article III of the Treaty of Peace, Friendship and Commerce signed in 1858 at Peking with China, Britain insisted that her Ambassador 'not be called upon to perform any ceremonial derogatory to him as representing the Sovereign of an independent nation on a footing of equality with that of China' ${ }^{78}$ What underlay this insistence, of course, was the perception that the Emperor had assumed for himself a misplaced 'superiority' in his dealings with European powers, and it was his inability to comprehend the notion of sovereign equality that required the matter to be forced home by use of arms. ${ }^{79}$ As the British government was later to explain, it was the 'wide gulf' that existed between Europe and America on the one hand, and China on the other, that gave rise to the imposition of unequal treaties. It noted, in particular, in that vein that:

"the conception of international relations as being intercourse between equal and independent States - a conception which was woven into the very texture of the political ideas of the nations of the West - was entirely alien to Chinese modes of thought". ${ }^{80}$

For the British then, unequal treaties followed from the Chinese inability to recognise or understand the notion of diplomatic or juridical equality. ${ }^{81}$

\footnotetext{
${ }^{77}$ As Fairbank was to describe it ('Tributary Trade', see previous note, pp. 132-3) "the relationship between the emperor and the barbarians [those outside Chinese civilisation] came to symbolize the actual historical relationship between China as the centre of culture and the rude tribes roundabout. This relationship was clearly recognized and formed the theoretical basis for the tributary system. The first tenet of this theory - and this is an interpretation - was that the uncultivated alien, however crass and stupid, could not but appreciate the superiority of Chinese civilization and would naturally seek to 'come and be transformed' (lai-hua) and so participate in its benefits. To do this it was chiefly essential that he should recognize the unique position of the Son of Heaven, the One Man who constituted the apex of the Chinese scheme of things. This confirmed with the fundamental dogma that China was the center of the human scene and that the emperor exercised the mandate of Heaven to rule all mankind, Chinese and barbarian alike."

${ }^{78}$ Hertslet's China Treaties, supra note 27, I, No. 6, p. 18.

${ }^{79}$ The theme of intervention for purposes of securing equality was one that was to garner considerable support. As one later antagonistic commentator put it in 1929 the "so-called Opium War" should correctly be described as "the struggle to vindicate the principle of the equality of Western nations with China”. Woodhead, supra note 6, p. 3.

${ }^{80}$ British Reply to Chinese Note to the Six Powers Concerning the Abolition of Extraterritoriality, Aug. 10th 1929 (Lampson), in Woodhead, supra note 6, pp. 60-61.

${ }^{81}$ A similar idea is found in Putney's assertion that exterritorial rights were "forced upon foreigners as a mark of inferiority" (Putney, supra note 41, p. 88).
} 
There was, of course, a paradoxical incompatibility within each of the positions adopted. The Chinese insisted - perhaps far beyond the stage at which it was really viable - in viewing the aggressive interlopers as tributepaying barbarians. The hierarchical inequality which underwrote the tribute system, and which had served well as a way of 'neutralising' the unfamiliar, ${ }^{82}$ was itself comprehensively undermined by the presence of foreign powers of equal, if not superior, military capability. The claim to moral or cultural superiority fell in face of the demands for equality premised upon power or force of arms. At the same time the European powers' insistence upon formal equality in diplomatic settings was itself comprehensively undermined by the presence of military forces that gave the lie to the non-hierarchical relations they espoused. Much as the Chinese were derided for their adherence to a pre-modern, and culturally incompatible, sense of superiority in face of the realities of international intercourse, so also the European interlopers might have been thought equally evasive in their insistence upon juridical equality. In some respects, the positions might have made more sense had they been reversed: the claim to equality being articulated in a context of powerlessness, and a claim to inequality issuing from a position of superiority. That they were not is, perhaps, of enduring significance: imperial domination being perfectly compatible with an insistence upon diplomatic and juridical equality.

When faced with the realities of diplomatic intercourse with polities in East Asia and elsewhere, international lawyers within Europe responded in a variety of ways. Some assumed that, in virtue of treaty relations with those States that they were already effectively members of the family of nations and therefore 'sovereign States'. Others, by contrast, doubted their place within the family of nations - taking the view that membership would only finally be acquired once they were able to participate in international relations as equals (once they had fully comprehended the terms of international law and once they were able to cast off the shackles of extraterritorial arrangements).

For those denying the membership of such nations in the international legal order - denying, in some senses, their 'sovereignty' - the question arose as to the basis upon which they could insist upon compliance with treaty obligations. In political or diplomatic terms, the question was obviously largely hypothetical (there was no sense in which those concluding the agreements

\footnotetext{
${ }^{82}$ See Fairbank ('Tributary Trade'), supra note 76, p. 137 (noting that the tribute system could operate as "a means of avoiding the dangers inherent in foreign relations on terms of equality". He suggests that the "secret of the whole system" was that "outsiders could have contact with China only on China's terms. These terms were in effect that the outsider should acknowledge and enter into the Chinese scheme of things and just to that extent become innocuous ... Tribute was a first step towards sinicizing the barbarian and so absorbing him . ..”).
} 
would not regard them as binding), but for international lawyers trying to respond to claims that the agreements in question were defective by reason of their inequality, or otherwise responding to the insistence that international law was primarily an expression of a European cultural identity, the point was hard to avoid. If such polities were not part of the system of international law (the 'family of nations'), how could they be treated as bound by the self-same system of law? International lawyers, of course, were not disposed to ignoring the realities of diplomatic concourse: however far they saw their profession as being one of moderating politics, they would not be fulfilling their evident professional function were they to declare such treaties either to be lacking in authority or purely 'political'. Engaging with the problem seemed to require an acceptance that such polities did enjoy some status, albeit a heavily qualified one, within the family of nations.

For those who were, in virtue of the realities of diplomatic intercourse, inclined to admit the legal nature of treaty relations with powers in East Asia, the real difficulty was how to square the putative membership of such States within the family of nations whilst recognising the implicit limits that had been placed upon their sovereignty in virtue of the arrangements. This problem was certainly one that would have engaged the classical authors such as Grotius $^{83}$ or de Vattel, ${ }^{84}$ each of whom spent some considerable time deliberating the point at which the idea of sovereignty gave way under external constraint. It would also have been one of concern to those 19th Century authors, such as Phillimore, Heffter, or Klüber who continued to hold the position that sovereignty entailed certain absolute or natural rights (such as the rights to self-preservation or independence) the consequences of which would seem to suppose either that States were entitled to ignore those agreements purporting to limit that sovereignty, or that such encumbrances, if not shaken off, had resulted in a loss of sovereignty. ${ }^{85} \mathrm{~A}$ certain number of later authors were to continue to pursue this line of thought albeit somewhat inconsistently. Pradier Fodéré, for example, was to argue in 1911 that:

${ }^{83}$ H. Grotius, De Jure Belli ac Pacis, Libri Tres (Bobbs-Merrill, trans. Kelsey, Indianapolis, 1925) pp. 394-5.

${ }^{84}$ E. de Vattel, Le Droit Des Gens, ou Principes de la Loi Naturelle, Appliqués a la Conduite aux Affaires des Nations et des Souverains (Carnegie, trans Fenwick, Washington, 1916) p. 165.

${ }^{85}$ A similar refrain is found in Wheaton (supra note $45, \mathrm{p} .44$ ) who suggests that "[t]he sovereignty of a particular state is not impaired by its occasional obedience to the commands of other states ... It is only when this obedience, or this influence, assumes the form of express compact, that the sovereignty of the State, inferior in power, is legally affected by its connection with the other ... Treaties of unequal alliance, guarantee, mediation, and protection, may have the effect of limiting and qualifying the sovereignty according to the stipulations of the treaties." 
"Cases must necessarily be admitted in which the State must be able to declare itself freed from any engagement, even when it has not expressly reserved this right by a clause of the treaty. Respect for engagements contracted should not, for example, be pushed to a suicidal extent. Though a State may be required to execute burdensome engagements contracted by it, it cannot be asked to sacrifice its development and its existence to the execution of the treaty." ${ }^{86}$

It is notable, however, that by the time Pradier Fodéré was writing, the terms of the original discussion had subtly changed. No longer was it a question of the inherent limits of sovereignty or a matter that went to the heart of identifying who were, or were not, members of the family of nations. Rather it was a question as to the legitimate basis for the termination of unwanted agreements: such agreements being valid until the moment arose in which they were declared to be unduly burdensome.

Since the sticking point appeared to be the early articulations of 'sovereignty', the obvious response was to reconsider what was implied by this notion. Westlake, Lorrimer, and Lawrence, amongst others, began the assault. For them, sovereigns were not all alike in terms of their powers and competences. In fact there existed several different classes of sovereign States: those part of the family of nations and those outside; those fully sovereign, those partly so; those enjoying some 'superintendence' within international relations (Great Powers) ${ }^{87}$ and those possessing merely 'ordinary' competence. ${ }^{88}$ In each case a complex taxonomy was built up running from,

${ }^{86}$ P. Pradier Fodéré, Traité de Droit International Public Européen et Américain (Pedone, Paris, 1911) II, p. 264. See also Oppenheim who maintained that:

"When the existence or the vital development of a state stands in unavoidable conflict with its treaty obligations, the latter must give way, for self-preservation and development, in accordance with the growth and the vital requirements of the nation, are the primary duties of every state. No state would consent to any such treaty as would hinder it in the fulfilment of these primary duties. The consent of a state to a treaty presupposes a conviction that it is not fraught with danger to its existence and vital development. For this reason every treaty implies a condition that if by an unforeseen change of circumstances an obligation stipulated in the treaty should imperil the existence or vital development of one of the parties, it should have a right to demand to be released from the obligation concerned."

L. Oppenheim, International Law: A Treatise (Longmans, 4th ed. McNair, London, 1926) I, p. 748 .

${ }^{87}$ See e.g., J. Westlake, International Law (Cambridge University Press, 2nd ed., Cambridge, 1910) I, pp. 321-2; Lawrence, supra note 74, p. 67; J. Lorimer, The Institutes of the Law of Nations (Blackwood, Edinburgh and London, 1883) I, pp. 93 et seq.

${ }^{88}$ Lawrence, however, continued to insist that " $[\mathrm{t}]$ here are many communities outside the sphere of international law, though they are independent States, they neither grant to others, 
at one end, semi-sovereign States (such as protectorates, protected States, suzerains), to Great Powers at the other. For them sovereignty was to shed its associations with abstract, pseudo-metaphysical, theory and embrace the reality of power politics. ${ }^{89}$ Both 'sovereignty' and 'equality' were to be redefined to accommodate the very real and palpable differences between States on the international plane.

By the early 20th Century this assault on sovereignty and its corollaries (sovereign equality, ${ }^{90}$ domestic jurisdiction) had come to a head. ${ }^{91}$ Whether or not as a result of trying to engage with polities on the periphery of Empire, ${ }^{92}$ or simply as a result of the emergence of 'positivism', ${ }^{93}$ sovereignty as a substantive concept had been comprehensively dismantled to the

not claim for themselves the strict observance of its rules" (ibid, p. 58). He continues unabashedly to observe that "[I]It would, for instance, be absurd to expect the Sultan of Morocco to establish a Prize Court, or to require the dwarfs of the central African forest to receive a permanent diplomatic mission" (ibid). For similar see Wheaton, supra note 45, p. 44.

${ }^{89}$ Brierly argues in similar vein in 1924 that the principles of international law "cannot be deduced from what they are so regarded a century ago, and still less from any pseudo-metaphysical notions of what the essential qualities of Statehood ought to be". (J. Brierly, "The Shortcomings of International Law', 5 British Yearbook of International Law (1924) p. 15).

${ }^{90}$ For a critique of the principle of State equality as a "creation of the publicists" drawing upon "the application to nations of theories of natural law" see E. Dickinson, The Equality of States in International Law (Harvard University Press, Cambridge, 1920) p. 334. See also Lorimer, supra note 87, II, p. 260 (n); E. Kaufmann, Das Wesen des Voelkerrechts und die Clausula Rebus sic Stantibus (1911) p. 195. McNair observes in an article written in 1927 that "[o]ne of the strongest movements in dynamic political science today is the attack upon sovereignty ... The undermining of the doctrine of the Equality of States seems to be a flank action on the same front." McNair, supra note 10, p. 134. Armstrong notes that the doctrine changed during the later years of the 19th Century, but that it remained important in the early years of the 20th Century in the form of the idea that "all nations should have an equal part in the formulation of the law and in the administration of the law". The Treaty of Versailles, however, represented an "abandonment" of the doctrine of equality "so far as it relates to international administration" and there was evidence to suggest that this would result in "the invasion by inequality of the status of nations in the formation and application of international law". S. Armstrong, "The Doctrine of the Equality of Nations in International Law and the Relation of the Doctrine to the Treaty of Versailles', 14 American Journal of International Law (1920) p. 544.

${ }^{91}$ Brierly refers to sovereignty as having become an " 'idolon theatre', bearing little resemblance to the actual position of States in their relation to one another" (Brierly, supra note 89, p. 13).

${ }^{92}$ Anghie, supra note 63.

${ }^{93}$ Kennedy associates a scepticism of sovereignty with positivism, supra, note 66, p. 114 (" $[\mathrm{t}$ ]o fulfil their polemical mission, to render plausible a legal order among sovereigns, the philosophy which sets this question, which makes sovereigns absolute or requires a sovereign for legal order, must be tempered, if not rejected. As a result, to inherit positivism is also to inherit a tradition of response to the scepticism and deference to absolute State authority, which renders legal order among sovereigns implausible in the first place".). 
point at which it no longer seemed to retain any real purchase on the issue. In the hands of the Permanent Court of Justice sovereignty was no longer to be articulated in terms of natural, or inherent rights, and gave rise to no particular consequences in its own right. ${ }^{94}$ The content of any State's sovereignty was rather to be understood in terms of a 'bundle of rights': that which is left to it (perhaps even 'delegated' to it) once its commitments under customary or conventional international law had been subtracted from a presumptive freedom of action..$^{95}$ This was to mean, on the one hand, that the legitimacy of any claim to autonomy in the name of sovereignty, was to be determined, not by a State's evaluation of its own self-interest, or by what it believed to be necessary for its self-preservation, but rather by the terms of a superordinating legal order. On the other hand, it would also mean that sovereignty was really to denote an abstract 'capacity' the content of which was almost entirely situation-specific and which was thereafter capable of being subsumed within a broader discourse of 'personality' (embracing both State, and institutional actors). Sovereignty, in other words, no longer imported any constraint upon the claim to validity of an agreement however unequal or however dictatorial its terms. If anything, it would do the opposite: the answer to the claims of East Asian States, thereafter coming in the form of an argument that they had, in virtue of their sovereignty, signed their sovereignty away. ${ }^{96}$

The underpinnings of this new order, of course, was the question of 'consent' - not consent, it must be said, to international law as a systemic enterprise, or to the idea that international law regulated State behaviour in a generative sense - but rather, and more specifically, of consent to the particularity of obligation. The growing reliance that international lawyers were to place upon consent as a way of conceptualising treaties - which assumed specific form in the reliance upon an analogy between treaties and contracts - led to an inevitable engagement with the problem of duress and revision.

${ }^{4}$ See e.g., Nationality Decrees in Tunis and Morocco Case, PCIJ Rep., Series B., No. 4 (1923) p. 24 (" $[\mathrm{t}]$ he question whether a certain matter is or is not solely within the jurisdiction of a state is an essentially relative question; it depends upon the development of international relations.”); Wimbledon Case, PCIJ Rep., Series A., No. 1 (1923) p. 25 (“"[n]o doubt any convention creating an obligation of this kind places a restriction on the exercise of sovereign rights of the State, in the sense that it requires them to be exercised in a certain way. But the right of entering into international engagements is an attribute of State sovereignty.").

${ }^{95}$ Cf. Lotus Case, PCIJ Rep., Series A, No. 10 (1927) (“'i]nternational law governs relations between independent States. The rules of law binding upon States therefore emanate from their own free will ... Restrictions upon the independence of States cannot therefore be presumed.").

${ }^{96}$ This relativisation of sovereignty also had its implications for the notion of equality. On this generally see Simpson, supra note 11. 


\subsection{Consent-Context: The Problem of Duress and Revision}

Throughout the 19th Century, international lawyers were faced with the difficulty of trying to simultaneously accommodate the idea that the binding quality of treaties derived from the consent of the parties thereto, whilst admitting that, even if only in certain contexts, consent appeared to be largely irrelevant. ${ }^{97}$ A central motif in their deliberations, in this sense, was an appreciation that European order at that time seemed to rest upon the terms of various peace treaties - the Final Act of the Congress of Vienna and associated agreements of 1815 , the Treaty of Paris of 1856, and the Treaty of Berlin of 1878 amongst others - in which the maintenance of a certain distribution of power overshadowed any concern for formal consent. ${ }^{98}$ Not only did the conditions central to the preservation of international peace seem to configure the salience of consent as a mode of validating treaties, but it was also evident that the existence of duress in its own right would not automatically be such as to invalidate an agreement. ${ }^{99}$ This, of course, did not mean that duress was always to be tolerated - the idea of consent, after all, remained an important legitimating device in the minds of international lawyers - but simply that any legal insistence upon a perfect exercise of voluntary will was to be understood as being conditioned by the context in which any particular agreement was to be found..$^{100}$

\footnotetext{
${ }^{97}$ Carr links this with the tolerance of war as a legitimate mode of pursuing national interest: "so long therefore as any kind of war whatever is recognized as moral, treaties concluded under duress cannot be unconditionally condemned as immoral". (supra note 18, p. 173).

${ }^{98}$ Carty notes that "both Britain and her opponents saw individual treaties in nineteenth century Europe as part of a framework of treaties which were to reflect as well as to maintain a material distribution of power" (supra, note 64, p. 67). Bederman similarly notes that peace treaties "were respected in an almost metaphorical way: they embodied the Concert of Europe”. D. Bederman, 'The 1871 London Declaration, Rebus Sic Stantibus and a Primitivist View of the Law of Nations', 82 American Journal of International Law (1988) p. 7. The 'realist' strain in 19th Century thought in this respect survived, in certain quarters, well into the 20th Century. See e.g. J. Stone, 'De Victoribus Victis: The International Law Commission and Imposed Treaties of Peace', 8 Virginia Journal of International Law (1967-68) pp. 357, 358 ("[w]hile finding it morally outrageous that . . . a treaty should be legally binding even if imposed at the end of a war by a victorious 'aggressor' on the victim of "aggression" [the writer has] seen no way of rescuing mankind by legal precept from this particular kind of outrage ... [There is no way] whereby international law can summon sufficient power to defeat every victor at the moment of his victory.").

${ }^{99}$ A. McNair, The Law of Treaties: British Practice and Opinions (Oxford University Press, Oxford, 1938) p. 129 ("[i]t is believed that the United Kingdom has at no time expressed any dissent from the current doctrine that a treaty is not rendered ipso facto void, and cannot be repudiated by one of the parties, by reason of the fact that such a party was coerced by the other party into concluding it, whether that coercion is applied at the time of signature or of ratification or at both times".).

${ }^{100}$ Bederman, supra note 98, p. 7.
} 
The simultaneous invocation of consent and context as a means of explaining the binding quality of treaties is fully evident in works such as Wheaton's Elements (which was incidentally the first major work to be translated into Chinese and Japanese and relied upon by advisors to those governments). In the 1866 edition Wheaton begins by relying, somewhat casually, upon a domestic analogy:

"By the general principles of private jurisprudence, recognised by most, if not all, civilised countries, a contract obtained by violence is void. Freedom of consent is essential to the validity of every agreement, and contracts obtained under duress are void, because the general welfare of society requires that they should be so."101

In privileging 'freedom of consent' as the source of validity of contractual (and hence treaty) obligations, Wheaton might be thought to call into question the legitimacy of any agreement procured by duress. Such a position, however, is significantly qualified by the reference, in his final phrase, to the 'general welfare of society'. It is not, he seems to say, the fact of consent alone that justifies the obligatory nature of treaty obligations - obligation not being linked, in that sense, to the prior value of a State's 'sovereign autonomy' (or the legitimating function that such an idea might serve) - but that the welfare of international society requires consent to have such an effect. On its own, this may be taken as having no great significance insofar as it simply replaces 'community' for 'autonomy' as the justification for his reliance upon consent. Yet in the following paragraph, all is made clear:

"On the other hand, the welfare of society requires that the engagements entered into by a nation under such duress as is implied by the defeat of its military forces, the distress of its people, and the occupation of its territories by an enemy, should be held binding; for if they were not, wars could only be terminated by the utter subjugation and ruin of the weaker party."102

For Wheaton, as for others writing at that time, the purity of a legal insistence upon consent had one major pre-condition: the maintenance of international peace. Only if peace was secure might one look to the presence of consent as a condition precedent for obligation. If peace demanded adherence to certain agreements, even if those agreements were procured by duress, it was to

${ }^{101}$ H. Wheaton, Elements of International Law 1866 (Clarendon Press, ed. Scott, Oxford, 1936) p. 284.

102 Ibid. 
espouse a dangerous idealism to argue otherwise. ${ }^{103}$ This, of course, was to lend such agreements something of a distinct aura. They could not readily be understood by way of analogy to contracts as later international lawyers were to insist. Rather, they seemed to assume the shape of constitutional arrangements that served, in some loose way, to define the nature of the society in which the rules of international law were to come into play. ${ }^{104}$ As Wheaton, himself, was to describe it:

"The obligation of treaties, by whatever denomination they may be called, is founded, not merely upon the contract itself, but upon those mutual relations between the two States, which may have induced them to enter into certain engagements." 105

An abstract rhetoric of consent premised upon sovereign autonomy, in other words, really didn't provide a sufficiently coherent explanation for the authority of treaty obligations. Treaties relied for their force less upon the idea that they were the substantiation of an autonomous expression of will, and rather more upon the political-diplomatic context (the balance of power, societal interest) in which they were located, and which they also seemed to describe. For lawyers writing in the middle of the 19th Century, then, the problem of treaties imposed by force of arms was likely to be regarded as a question of politics or diplomacy as much as, if not more than, one of law; opposing unequal treaties was to oppose not merely the institution itself, but also the politics that lay behind it.

\subsubsection{Rebus Sic Stantibus}

Even if, however, international lawyers were to attune themselves to the importance of political context for the authority of treaties - and to accept on sufferance the limits of their own legal endeavour - this did not prevent the

\footnotetext{
${ }^{103}$ In some quarters a similar, but countervailing, argument was to operate. If international law was premised upon the dictates of peace and good order, and if that could only be ensured so long as the survival of States was not at stake, one could only admit the legitimacy of duress so long as the agreement did not put the very existence of a State into question. Thus Hall was to argue that international law regards "all compacts as valid notwithstanding the use of force or intimidation" but that if such an agreement were to threaten to destroy the independence of a State, "constraint vitiates the agreement, because it cannot be supposed that a State would voluntarily commit suicide by way of reparation or as a measure of protection to another". Hall, supra note 73 , s. 108.

${ }^{104}$ For an implicit reliance upon this idea as a way of describing the recent epochs of international relations, see P. Bobbitt, The Shield of Achilles: War, Peace and the Course of History (Penguin, London, 2002).

${ }^{105}$ Wheaton, supra note 45 , p. 39.
} 
problem of unequal treaties from appearing again: this time in the form of an argument as to a right of unilateral termination under the title rebus sic stantibus. ${ }^{106}$ If the sanctity of peace agreements lay in their putative role in the preservation of peace and good order, there was always the possibility that the terms of those politics might change (that the 'balance' of power might shift - that the weak become powerful or the powerful weak) and hence render the agreements essentially obsolete ${ }^{107}$ or perhaps even dangerous. This was the sense of the Russian contentions of 1870 justifying its repudiation of the Black Sea clauses (Articles 11, 12 and 13) in the Treaty of Paris ${ }^{108}$ and those of Austria-Hungary following its annexation of Bosnia-Herzegovina in 1907. ${ }^{109}$ It may also, incidentally, have lain behind the renegotiation of treaties with Japan in the late 19th Century following several decades of internal reform and 'Westernisation'. The response at the time to such contentions - coming, most overtly, in the form of the London Protocol of 1871 was one of pure evasion. Whilst insisting on the 'sanctity of treaties' and providing that treaty engagements might only be terminated with the consent of other parties, ${ }^{110}$ the London Protocol neatly disposed of continuing ambivalence as regards the contemporaneous impulses for stability and change

\footnotetext{
${ }^{106}$ The relationship between contextual power relations and the doctrine rebus sic stantibus is noted by Carr who remarks that "[t]his doctrine, if carried to its logical conclusion, would appear to lead to the position that a treaty had no authority other than the power relationship of the parties to it, and that when this relationship alters the treaty lapses". Carr, supra note 18, p. 169. For an explicit endorsement of this idea see C. Elliott, 'The Shantung Question', 13 American Journal of International Law (1919) p. 698 ("[i]n international practice [imposed treaties] are common and are recognized as valid with the implication and expectation that they will be repudiated whenever the injured state has acquired the military power necessary to make the renunciation effective.").

${ }^{107}$ Associated with this idea is that expressed by Pradier Fodéré (supra, text accompanying note 86) to the effect that treaties may be unilaterally revoked if they conflict with the "vital interests' or 'self preservation' of the State. In some senses this represented a continuation of the 'natural rights' thesis that held sway in the early 19th Century, but it was equally consistent with the notion that the idea that a 'consensual' international law was to operate subject to overriding considerations of political necessity.

${ }^{108}$ McNair speaks of the invocation of rebus sic stantibus as an 'undercurrent' (supra note 99, p. 351).

${ }^{109}$ The annexation was inconsistent with Article 25 of the 1878 Treaty of Berlin in which European Powers had agreed to the occupation and administration of the Turkish provinces of Bosnia and Herzegovina by Austria-Hungary.

${ }^{110}$ The London Protocol of January 17th 1871 provided that:
}

"It is an essential principle of the Law of Nations that no Power can liberate itself from the engagements of a Treaty, nor modify the stipulations thereof, unless with the consent of the Contracting Parties by means of an amicable arrangement". 
within Europe. Whilst in form at least, it upheld a commitment to the sanctity of treaties, its relevance was significantly undermined by the fact that in each and every case, modification of the agreements in question was subsequently accepted. ${ }^{111}$ What the Protocol evidently didn't clarify, however, was either the relationship between the principle of consent and background alterations in the terms of power (i.e. whether it actually applied in case of a fundamental change of circumstances ${ }^{112}$ ), or the possibility that consent may not actually be forthcoming ${ }^{113}$ (in which case, one may suppose, recourse to military force might have ensued).

It was precisely these problems that confronted international lawyers in the aftermath of the 1914-1918 War. On the one hand, it was apparent that a number of German scholars had advanced the view that Germany was fully justified in unilaterally terminating the Treaty of London of 1839 (providing for Belgian neutralisation) on the basis of changed circumstances (the growth of the Belgian population and its acquisition of the Belgian Congo). ${ }^{114}$ On the other hand, it was equally apparent that British commitment to the same treaty ${ }^{115}$ - its insistence upon seeking to maintain the balance of power that the treaty, however imperfectly, articulated - had effectively escalated the conflict. Neither insisting upon the sanctity of treaties, nor allowing an unfettered right of unilateral termination appeared to be a viable way of contributing to the preservation of international peace, and the intimate connection between the honouring of treaties and the preservation of European public order that had marked legal thought throughout much of the previous Century seemed to evaporate. ${ }^{116}$

${ }^{111}$ See generally, Bederman, supra note 98, pp. 15-17; Carty, supra note 64.

${ }^{112} C f$. L. Woolsey, 'The Unilateral Termination of Treaties', 20 American Journal of International Law (1926) p. 349 ("[t]his declaration . . . would seem to amount to no more than a declaration that a treaty cannot be annulled by one of the parties without the consent of the other in circumstances which involve no change in the fundamental conditions on which the treaty is based and which show no violation of the treaty by the other party.").

${ }^{113}$ Cf. Brierly, supra note 89, p. 16.

${ }^{114}$ See C. de Visscher, Belgium's Case: A Juridical Enquiry (Hodder and Stoughton, trans E. Jourdain, London, 1916). This contention was roundly dismissed by lawyers elsewhere as a denial of law, see e.g., E. Root, 'The Outlook for International Law', 10 American Journal of International Law (1916) p. 1.

${ }^{115}$ Cf. Treaty of Versailles, 1919, Article 232.

${ }^{116}$ Quincy Wright begins his article on the 'Legal Nature of Treaties' (10 American Journal of International Law (1916) p. 706) with the following question:

"the recent failure of a treaty, just at the time when a Third Hague Conference was due, is of unusual significance. It marked a break in the steady progress which codification had made in international law since the Declaration of Paris of 1856. If a treaty, ratified and reaffirmed with such solemnity as the Belgian Neutralization 
In the projects of 'renewal' in the aftermath of the First World War, international lawyers proceeded to grapple with what later came to be known as the problem of 'peaceful change'. ${ }^{117}$ The question that seemed to confront them was how they could maintain an insistence upon the sanctity of treaties (and, hence, faith in international law's ability to regularise politics) whilst simultaneously admitting that preserving the status quo might be fundamentally dangerous. Whilst many remained enticed by the ideas of Maine ${ }^{118}$ and Savigny ${ }^{119}$ in the 19th Century who had intimated that law would evolve with the society in which it was found, they were also aware of the regressive potential of 'perpetual' or 'obsolete' treaties, and the absence of any obvious mechanism by which law could be altered to reflect the changing needs or aspirations of international society. Some way had to be found to allow some treaties to be changed without bringing the whole edifice of law crashing to the ground: how could they explain to the Chinese that unilateral termination was not an option whilst allowing others to readily engage in precisely the same process?

The immediate way out of this impasse for international lawyers was to separate their concern for peace and good order from their rationalisation as to the binding force of treaties. Whether or not as a result of a misplaced confidence in the institutions of the League of Nations, ${ }^{120}$ or simply by reason of a 'positivist' desire to separate the fields of law and politics, international lawyers began to treat the problem of order as an essentially political or legislative issue rather than one that emanated from reliance upon treaties of alliance or

Treaty, was worthless, were not the hopes for world organization and codified international law by means of conventions pretty thoroughly shattered?"

${ }^{117}$ See Brierly, (supra note 89) pp. 8-9; J. Kunz, 'The Problem of Revision in International Law ("Peaceful Change")' 33 American Journal of International Law (1939) p. 33; C. Manning, Peaceful Change. An International Problem (Macmillan, London, 1937).

${ }^{118}$ H. Maine, Ancient Law (London, 1861).

${ }^{119}$ Wheaton, for example, in the introduction to his 1866 edition of the Elements (supra note 100, p. 8) quotes Savigny (System des heutigen römischen Rechts, I, I, ii, 11) with approval:

"there may exist between different nations the same community of ideas which contributes to form the positive unwritten law (das positive Recht) of a particular nation. This community of ideas, founded upon a common origin and religious faith, constitutes international law as we see it existing among the Christian States of Europe."

${ }^{120}$ See Carty, supra note 64, p. 80 ("[i]t is clear from the work of Lauterpacht and Brierly that juridical analysis of treaty obligations after 1918 can only be understood in the wider context of a commitment to the goal of supranational organisation. Jurists drew analogies between international and municipal law concepts within a framework which was to replace the politics of international relations with institutions approximating as far as possible to those of a world State.”). 
guarantee. Having freed themselves, thereby, from the strictures of understanding compliance with treaties in terms of their contextual or political significance, international lawyers were then able to talk about the perfection of the analogy between treaties and contracts. Once, in other words, the League had begun the process of seeking to limit or constrain recourse to force (once they were able to displace their concern for order in the 'move to institutions') - treaties could thereafter be understood as agreements governed by international law, whose binding force depended upon the 'autonomous will of the parties'. ${ }^{121}$

This separation between problems of order and problems of contract was particularly evident in the treatment of the doctrine rebus sic stantibus. Whereas, as suggested above, in the 19th Century the doctrine was associated with the idea of maintaining the integrity of the European order (or alternatively with the innate incapacity of States to legislate themselves out of existence), in the 1920 s it came to be divided into two separate issues one being the 'political' issue of treaty revision (which the terms of Article $19^{122}$ of the League of Nations Covenant were designed to address) ${ }^{123}$ the other being the more narrow issue of the 'clausula' whose sense was simply to give effect to the intuited intentions of the parties. ${ }^{124}$ Article 19 addressed

${ }^{121}$ See on this H. Lauterpacht, Private Law Sources and Analogies of International Law (Longmans, London, 1927) pp. 155-167; A. McNair, 'So-Called State Servitudes', 6 British Yearbook of International Law (1925) p. 122 (“"[m]ost treaties or conventions between states are jurisprudentially contracts, and the private law of contract has proved an important source of rules for their formation, interpretation and dissolution.").

${ }^{122}$ Article 19 provided that the League Assembly might from time to time advise the reconsideration by member States of "treaties which have become inapplicable and the consideration of international conditions whose continuance might endanger the peace of the world."

${ }^{123}$ As Kunz was to argue in 1939 (supra note 117, p. 42):

"The problem of revision often comes up in practice because of the positive norm that peace treaties, although imposed by force, are legally valid. But in spite of this connection, the two problems have to be distinguished clearly. The problem of validity in spite of force is a problem of positive law; the second, asking for modification because of the fact that the treaty has been imposed by force, is a political, legislative problem, a problem of revision."

${ }^{124}$ For an elaboration of these two senses of the doctrine see Lauterpacht, supra note 121, pp. 167-9; J. Brierly, The Law of Nations (Oxford University Press, 6th ed., Oxford, 1963) pp. 336-8; Kunz, supra note 117, p. 197; J. Fischer Williams, 'The Permanence of Treaties', 22 American Journal of International Law. (1928) p. 91; G. Scelle, Théorie juridique de la révision des traités (Paris, Sirey, 1936) pp. 14-29. Cf. D. Kennedy, 'The Sources of International Law', 2 American University Journal of International Law and Politics (1987) pp. 57-60 ("rebus sic stantibus has two faces, one consensual (in which the clausula is inserted into all international agreements) the other premised upon justice (in which it functions as a means of preserving justice)"). 
the relationship between the sanctity of treaties and the maintenance of public order; the clausula addressed the relationship between consent and changed circumstances. The former was a public issue capable of being addressed only in legislative fora, the latter essentially private and thereby suited to judicial determination (particularly salient given the creation of the Permanent Court). ${ }^{125}$

The experience of China in the early years of the 20th Century suggested that much of the potential force of the doctrine had been neutralised by this separation of the issues. On the one hand it sought, with very limited success, renegotiation of the agreements both by way of petitioning the League Assembly under Article 19 and by Conference diplomacy. On the other hand, having invoked a right of unilateral termination in the case of the SinoBelgian Treaty of $1865,{ }^{126}$ it faced the prospect of the Permanent Court deciding, perhaps with one eye to German agitation with respect to the Versailles settlement, that treaties however unequal are incapable of denunciation. ${ }^{127}$ Although the matter was finally settled by agreement, China's refusal to participate in proceedings was perhaps prescient. ${ }^{128}$ As the Court was later to make clear in the Free Zones case, a change in circumstance (assuming, indeed, that the doctrine was a recognised one) would only warrant the conclusion that a treaty had lapsed if the circumstances in question had been a central consideration in the minds of those negotiating the agreement. ${ }^{129}$ For the Chinese, of course, this cut away many of their objections to the agreements in question: the issue of duress would be of no significance, nor would be those associated with the huge increase in the number of foreign

${ }^{125}$ The creation of a international court capable of determining when, and under what circumstances a treaty obligation may be set aside was, in many respects, the key to this distinction. See e.g., Oppenheim, supra note 86, p. 693 (The value of the Declaration of London "must remain doubtful until an independent international court is created with jurisdiction to set aside a treaty obligation which has become too oppressive"). Some, such as Putney, continued to hold to the 19th Century view, concluding that "the question of the termination of unequal treaties is at least at present not a matter of a strict legal right, nor a matter which can be settled by arbitration of before any world court of The Hague. It is still a question of diplomacy, and to a large extent, a question of force, as to what a country is able to secure." Putney, supra note 41, p. 90.

${ }^{126}$ Denunciation of the Treaty of Nov. 2nd 1856 Between China and Belgium P.C.I.J. Rep. Series A, No. 8 (1927) pp. 4-5.

${ }^{127}$ The President of the Court ordered provisional measures for the protection of Belgian rights under the agreement. Order of 8 January 1927, ibid, p. 6.

${ }^{128}$ China argued that its declaration was consistent with Article 19 of the Covenant of the League and, therefore, if any appeal against termination were to be made, it should go to the Assembly of the League rather than to a judicial tribunal.

${ }^{129}$ Free Zones of Upper Savoy and the District of Gex, PCIJ, Series A/B, No. 46 (1932) 96, pp. 156-8. 
nationals resident in China, or the continued economic consequences for the national budget of operating restricted tariff rates.

Whilst some modification of the doctrine rebus sic stantibus evidently took place in the drafting of Article 62 of the Vienna Convention (e.g. in terms of it being constructed as an 'objective rule' rather than as a tacit condition $^{130}$ ) its general shape as articulated by the Permanent Court remained intact. Article 62 was articulated by the International Law Commission as a 'safety valve' - protecting the integrity of treaties (and of international law more generally) by admitting the possibility of denunciation. To avoid it being employed by way of avoiding 'inconvenient treaties' however, it was confined 'within narrow limits'. ${ }^{131}$ According to Article 62 (which according to the ICJ is to be taken as a "codification of existing customary law on the subject of the termination of a treaty relationship on account of change of circumstances" ${ }^{\prime 132}$ ) a treaty is terminable only where an unforeseen change in the circumstances underlying the conclusion of the treaty "transforms radically the extent of the obligations still to be performed". Its purpose is not, in that sense, to allow termination of treaties imposed in unequal circumstances, or by dint of coercion: original inequality is relevant only where it becomes either less or more so over time, and then only when it constituted an essential basis of the consent of the parties to be bound by the treaty. ${ }^{133}$

Both the limits of the doctrine, and the rationale for its limitation, are clearly exposed in Brierly's discussion of the issue in 1963. Brierly makes clear that the doctrine, thus elaborated, was never really intended to deal with the problem of oppressive treaties:

"We may well hold that the obligation of a treaty comes to an end if an event happens which the parties intended, or which we are justified in presuming they would have intended, should put an end to it; the more difficult problem concerns an obligation which the parties did not intend to be ended, but which it would be oppressive to

${ }^{130}$ See e.g., Commentary to article 59, Yearbook of the International Law Commission (1966/II), para. 7.

${ }^{131}$ Ibid, para. 1.

${ }^{132}$ Fisheries Jurisdiction Case, ICJ Rep. (1973) p. 63, para. 36.

${ }^{133}$ See Caflisch, supra note 1, pp. 77-8 (The doctrine rebus sic stantibus "is only marginally germane to the issue of 'unequal' treaties ... The unequal treaty argument could be raised in the context of rebus sic stantibus, but only inasmuch as the alleged change of circumstances has turned an initially 'equal' agreement into an 'unequal' one.”) In Gabcikovo the ICJ affirmed that "prevalent political conditions" had to be "so closely linked to the object and purpose of the Treaty that they constituted an essential basis of the consent of the parties and, in changing, radically altered the extent of the obligations still to be performed". Case Concerning the Gabcikovo-Nagymaros Project, ICJ Rep. 1997, para. 104. 
enforce, and which will probably in fact be violated . . It is because so many writers have sought to find in rebus sic stantibus a solution for this latter problem that the doctrine has become of the most controversial in international law." 134

He continues by observing that for oppressive treaties:

"the only remedy is that states should be willing to take measures to bring the legal situation into accord with new needs, and if states are not reasonable enough to do that, we must not expect the existing law to relieve them of the consequences. Law is bound to uphold the principle that treaties are to be observed; it cannot be made an instrument for revising them, and if political motives sometimes lead to a treaty being treated as a 'scrap of paper' we must not invent a pseudo-legal principle to justify such action. The remedy has to be sought elsewhere, in political, not in juridical action."135

One finds here a clear sense of how the doctrine of changed circumstances is related to the imputed limits of law: law cannot, without losing a sense of its distinctive mission, ${ }^{136}$ regulate matters that are more properly the domain of politics. 'Let us make it clear', Brierly seems to say, 'where the limits of law lie', and 'let us not allow the purity of law to be invaded by unreasoned politics'. ${ }^{137}$ Politics begins where law ends, and vice versa. No sense is given to the idea that a failure to engage with the politics of inequality in the name of preserving the purity of law may be equally 'political', or that the jurist's commitment to upholding treaties, however onerous, may do equal disservice to the ideals of law to which he apparently subscribed as might an admission that treaties might be terminable on that basis. For Brierly, and others no doubt, more was to be lost by seeking to modify the application of pacta sunt servanda than by exposing international law to the possibility of treaties being disregarded: ${ }^{138}$ his

${ }^{134}$ Brierly, supra note 124 , p. 338-9.

135 Ibid, p. 339.

${ }^{136}$ The function assigned to international law by Brierly was to enable "States to carry on their day-to-day intercourse along orderly and predictable lines" (ibid, p. 78).

${ }^{137}$ For a similar distinction between the 'just and necessary' elements of the clausula and those regarded as 'the very negation of law' see Lauterpacht, supra note 121 pp. 167-75 ("A treaty may become obsolete, oppressive, and out of accord either with postulates of justice or with political and economic conditions, and yet it need not necessarily come within the scope of the legal application of the clausula. The remedy is here obviously a political one, and it lies within the competence of the international legislature, but not of the international judiciary." (p. 174)).

${ }^{138}$ There is a palpable shift in Brierly's views on this. In his earlier 'Shortcomings' Brierly was to pose the question whether insisting upon the sanctity of pacta sunt servanda was necessarily desirable (supra note 89 , p. 16). 
premonition, perhaps, being that in case of oppressive treaties, politics and law would actually work in the same direction - only the powerful being competent to terminate an agreement, the powerless bound by the realities of politics as much as law.

\subsubsection{Duress}

As suggested above, what was of significance in the elaboration of the doctrine of rebus sic stantibus in this manner was the development of a general prohibition on use of force in the form of the Kellogg-Briand pact and Article 2(4) of the UN Charter. If the legal regulation of armed conflict encouraged, using Lauterpacht's words, "the restoration of the missing link of analogy of contracts and treaties, i.e. of the freedom of will as a requirement for the validity of treaties"139 it did so only so far as it made inadmissible the exercise of duress in the conclusion of an agreement. Whilst jurists were reluctant to perfect this move in the inter-war years (particularly insofar as the terms of the Treaty of Versailles itself would have been called into question $)^{140}$ such a position came to be enunciated in the form of Article 52 of the Vienna Convention which renders void any treaty procured by the threat or use of force in violation of the principles of the United Nations Charter. ${ }^{141}$ For many, this would now seem to undercut the contentions that fuelled opposition to the unequal treaties of the 19th Century.

Lauterpacht's remarks upon the relationship between the admissibility of duress and the perfection of the contractual analogy are, however, enlightening.

${ }^{139}$ Lauterpacht, supra note 121, p. 166.

${ }^{140}$ See e.g., Scelle, supra note 117, p. 16; J. Kunz, 'The Meaning and Scope of the Norm Pacta Sunt Servanda', 39 American Journal of International Law (1945) p. 185; McNair, supra note 99, pp. 139-40). Such a position was also apparently upheld by Fitzmaurice in his reports to the ILC concerning the effect of duress, Yearbook of the International Law Commission (1958/II) 20, p. 26. But see Article 4(3) Harvard Draft Convention on Rights and Duties of States in Case of Aggression, 33 American Journal of International Law (Supp. 1939) p. 895 (“[a] treaty brought about by an aggresssor's use of armed force is voidable”). Concern over the Munich agreement was clearly a considerable spur in this regard. See e.g., Q. Wright, 'The Munich Settlement and International Law', 33 American Journal of International Law (1939) pp. 22-3 (arguing that the authors of the Munich Settlement had erred in the same way as had those of the Versailles agreement, in placing substance before procedure).

${ }^{141}$ Cf. Fisheries Jurisdiction Case, ICJ Rep. (1973) 14, p. 59 ("[t]here can be little doubt, as is implied in the Charter of the United Nations and recognized in Article 52 of the Vienna Convention on the Law of Treaties, that under contemporary international law an agreement concluded under the threat or use of force is void."). 
Having reviewed the work of a number of contemporary authors, he comes to the conclusion that:

"It is not intended, by putting forward the view so these publicists, to call into doubt the well-established rule of international law as to the admissibility of duress. What is intended is to stress the fact that the recognition of compulsion is qualified, with a strong and authoritative body of publicists, by the postulate that it should be lawful and just. Compulsion thus conceived does not fall under the category of duress, but of enforcement of law." [italics added]

Carrying this idea forward to the elaboration of the principle articulated in Article 52 of the Vienna Convention one can readily see the point. By its reference to the UN Charter, Article 52 situates the problem of duress within the framework of Charter principles governing coercion. As the Charter (to use the Schmittian tautology) only prohibits the 'unlawful use of force', ${ }^{142}$ and hence leaves open the possibility of defensive wars, wars authorised by the Council itself, ${ }^{143}$ and the use of coercion that falls someway short of 'armed force' itself ${ }^{144}$ - the problem of duress can only be regarded as fully addressed to the extent that such coercion is reconceptualised either as a matter of law enforcement, or perhaps, more simply, as lawful coercion. ${ }^{145}$

\footnotetext{
${ }^{142}$ Schmitt remarks (The Concept of the Political, (MIT Press, Cambridge Mass., 1996) p. 49) that "to demand of a politically united people that it wage war for a just cause only is either something self-evident, if it means that war can be risked only against a real enemy, or it is a hidden political aspiration of some other party to wrest from the state its jus belli and to find norms of justice whose content and application in the concrete case is not decided upon by the state but by another party, and thereby it determines who the enemy is." He continues (pp. 50-1) by remarking that the Kellogg Pact "neither repudiated war as an instrument of international politics ... nor condemned nor outlawed war altogether". This, he reasoned followed from the fact that the declaration was subject to specific exceptions such as self-defence which, far from being mere exceptions, gave the norm its concrete content - it was for each state to determine for itself the justification in question. He concluded, in that respect that "the solemn declaration of outlawing war does not abolish the friend-enemy distinction, but, on the contrary, opens new possibilities by giving an international hostis declaration new content and new vigour". Thus (on p. 56) he concludes, "the Geneva League of Nations does not eliminate the possibility of wars, just as it does not abolish states. It introduces new possibilities for wars to take place, sanctions coalition wars, and by legitimizing and sanctioning certain wars it sweeps away many obstacles to war."

${ }^{143} \mathrm{Cf}$. commentary to Article 75 Vienna Convention, supra note 130.

${ }^{144}$ On economic coercion see, Declaration on the prohibition of military, political and economic coercion in the conclusion of treaties, annexed to the Final Act of the Vienna Conference on the Law of Treaties, UN Doc. A/CONF.39/26. An account of proceedings leading to the declaration may be found in C. Murphy, 'Economic Duress and Unequal Treaties', 11 Virginia Journal of International Law (1970) p. 51.

${ }^{145}$ Brierly makes a similar point (supra note 124, p. 319): "The true anomaly in the present law is not that it should be legal to coerce a state into accepting obligations which it does not
} 
Article 52, in other words, separates the existence of coercion preliminary to the conclusion of an agreement, from the identification of 'duress' as a feature that nullifies the effect of such an agreement: only if the former is treated as 'unlawful' would the issue of duress ever be entertained, even if, that is, there was no doubt as to the significance of the coercion in procuring the consent of the subordinate party.

There are two particular consequences that seem to flow from this. The first, obvious, point is that the prohibition on duress is thereby largely conditioned by the extent to which any prior use of coercion is regarded as unlawful. ${ }^{146}$ Quite apart from the initial systematic separation of economic from physical coercion that this appears to entail (a separation which brings to mind all sorts of neo-colonialist connotations ${ }^{147}$ ), there is a dependence here upon the self-evident nature of the legal assessment. Even if the conclusion of the Treaty of Nanking may have fallen within such terms (assuming that the British would not have spoken about their recourse to arms in terms of self-defence) the same may not be said about the threat of force that hung in the air at the time of concluding the Ansei Treaties with Japan, or those with Siam. ${ }^{148}$ To the extent, then, that any use of coercion is liable to be accompanied by some justificatory discourse - whether premised upon the UN Charter itself, or some modification thereof - those disputing the validity of an agreement would be constantly fighting a rearguard battle. This is all the more evident given the ICJ's insistence in the Fisheries Jurisdiction case, that any 'accusation' of coercion for purposes of disputing the validity of an agreement had to be accompanied by 'clear evidence' that went above and beyond the mere presence of naval forces off the coast of the State concerned. ${ }^{149}$

like, but that it should be legal for a state which has been victorious in a war to do the coercing; and the change to which we ought to look forward is not the elimination of the use of coercion from the transaction, but the establishment of international machinery to ensure that when coercion is used it shall be in a proper case and by due process of law, and not, as present it may be, arbitrarily."

${ }^{146}$ Under Article 75, provisions of the Vienna Convention "are without prejudice to any obligation in relation to a treaty which may arise for an aggressor state in consequence of measures taken in conformity with the Charter of the United Nations with reference to that State's aggression".

${ }^{147} C f$. A. Anghie, 'Colonialism and the Birth of International Institutions: Sovereignty, Economy, and the Mandate System of the League of Nations', 34 New York University Journal of International Law and Politics (2002) (who speaks about the "economization of sovereignty" as part of a neo-colonialist project).

${ }^{148}$ Keeton was to maintain in 1929 that "even if international law only recognizes treaties freely entered into, this would include most of the treaties concluded by Foreign Powers with China last century (except those of Great Britain, France and Japan)". G. Keeton, 'The Revision Clause in Certain Chinese Treaties', 10 British Yearbook of International Law (1929) p. 114.

${ }^{149}$ Fisheries Jurisdiction Case (Jurisdiction), ICJ Rep. (1973) p. 14, para. 24. 
A second, and more general point, is that if coercion and duress are separated in this way, any argument that the prohibition of duress is essential for purposes of ensuring autonomous consent as a constitutive feature of treaty obligations is that much harder to maintain. ${ }^{150}$ If coercion is largely compatible with consent, the problem would not seem to be a problem of treaty law, but rather, as Brierly suggests, 'a particular aspect of that much wider problem which pervades the whole system, that of subordinating the use of force to law'. ${ }^{151}$ This is taken up by Sinclair who, in his analysis of the Vienna Convention, suggests that:

"coercion of a State by the threat or use of force does not, strictly speaking, vitiate consent; it rather involves the commission of an international delict with all the sanctions attached thereto." ${ }^{152}$

In a positive sense, Sinclair seems to draw upon the point made by Lauterpacht to the effect that the nullification of an agreement following an unlawful act could, in some senses, be regarded as analogous to an obligation not to recognise an unlawful situation. ${ }^{153}$ Whilst for Lauterpacht this was a crucial move in his articulation of the emergent prohibition on duress, for Sinclair it clearly works in a different direction. Having discussed the perils of giving heed to the idea of economic duress, ${ }^{154}$ he goes on to suggest that 'consent' needed to be stripped of its associations with a factual 'absence of coercion'. Consent, accordingly, was to be understood less as an expression of 'autonomous will' and rather more as the formal mode of acceptance of an instrument - signified by signature, ratification or accession - in which any psycho-sociology of 'agreement' was beyond the domain of law, and in which the presence or absence of duress was largely irrelevant. ${ }^{155}$ Duress

\footnotetext{
${ }^{150}$ Caflisch remarks that "[a]n imbalance of treaty obligations might carry a conclusive presumption or at least the suggestion that a party, on account of its political or economic dependence from its partner(s), did not enter into the treaty out of its own free will, for no 'reasonable State' can be assumed to have concluded an agreement disadvantageous to it". (supra note 1, p. 53). This supposition is later rejected by the author as unfounded.

${ }^{151}$ Ibid.

${ }^{152}$ I. Sinclair, The Vienna Convention on the Law of Treaties (Manchester University Press, Manchester, 1984) p. 180.

${ }^{153}$ See also I. Brownlie, International Law and the Use of Force by States (Oxford University Press, Oxford, 1963) p. 404-5 ("State practice in regard to the effect of duress is in part connected with the development of the principle of non-recognition of territorial acquisitions obtained by the threat or use of force.").

${ }^{154}$ Sinclair, supra note 152 , p. 178 ("[a]cceptance of the concept that economic pressure could operate to render a treaty null and void would appear, if these sweeping views as to the dominant position of developed countries were accepted, to invite claims which would put at risk any treaty concluded between a developing and a developed country.").

${ }^{155}$ See e.g., Memorandum of the Solicitor for the Department of State, 30 June 1921 in which it was noted, in reference to German signature of the Treaty of Versailles, that "even
} 
comes to operate, in such a context, as an independent variable that may (or may not) render an agreement invalid, rather than something that goes to an evaluation as to whether or not there has been an agreement in the first place $^{156}$ - its toleration being symptomatic of the inadequacies of any mechanism for the political rendering of sanctions, rather than something that cut to the heart of the notion pacta sunt servanda. Once the argument has moved to this point, it is more than evident that the problem is subtly shifted out of law and into politics. Lawyers could rely upon a presumption of validity as a way of insulating themselves against the possibility that consent might all too often be found defective; it was for the politicians to devise ways of ensuring that untoward influence is not exercised at the moment of negotiation.

\subsection{Consent-Content/Form: The Problem of Reciprocity}

Like the problem of context, that of reciprocity was answered, for 19th lawyers, by the existence of Peace Agreements as a legal phenomenon. So long as peace agreements assumed a significant role in European diplomacy insisting upon reciprocity in either the form or content of treaties did not offer itself as a viable intellectual pursuit. Indeed reciprocity was not an issue with which lawyers typically concerned themselves at that time; of more concern was the question whether treaties could be regarded as mere 'agreements' between States for purposes of settling local difficulties, or as "a sort of sancrosanct repositary in which the most fundamental principles and binding rules of the law of nations are to be found". ${ }^{157}$ Even Triepel's famous distinction $^{158}$ between the Vertrag (Contract treaty) and the Vereinbarung

though a vanquished nation is in effect compelled to sign a treaty, I think that in contemplation of law its signature is regarded as voluntary", cited in G. Hackworth, Digest of International Law (US Gov. Printing Office, Washington, 1940) V, p. 158.

${ }^{156}$ This point is taken up by Nahlik who notes that Sir Humphrey Waldock, Special Rapporteur of the International Law Comission for the law of treaties, "chose to speak about invalidity only, with hardly anything stated about validity of treaties". This "negative" approach to the issue necessarily placed "a presumption in favour of the validity and binding force of treaties. A treaty, any treaty, is presumed to be valid and in force unless one of the grounds listed in the convention has occurred." S. Nahlik, 'The Grounds of Invalidity and Termination of Treaties', 65 American Journal of International Law (1971) pp. 738, 739-40.

${ }^{157}$ Lawrence, supra note 74, p. 94 (who articulated the distinction in terms of two competing views - one associated with common law countries (Britain and the United States), the other with the continental tradition). Similar distinctions were identified by other authors: such as those between transitory conventions and treaties (H. Wheaton, Elements of International Law (8th ed. Dana, Boston, 1866), p. 340) and between executed and executory treaties (Westlake, (supra note 87) I, pp. 60, 61).

${ }^{158}$ Lauterpacht (supra note 121) insists that the distinction is, in fact, traceable to Bergbohm in 1877. 
(Law-making treaty), ${ }^{159}$ which might well have been cast in terms of the relative significance of reciprocity, was in fact articulated in terms of whether the agreement committed each party to achieve the same, or different, ends. ${ }^{160}$ Reciprocity was certainly not a sine qua non for their evaluation as to the authority of international agreements.

For early 20th Century international lawyers, however, as with their 18th Century counterparts, the issue of assymetrical relations seemed to be more challenging. If a treaty was to be essentially understood as some form of contract, ${ }^{161}$ the presence or absence of some element of quid pro quo seemed all the more important. Absent some substantive exchange, an instrument might all too easily be re-characterised as essentially a unilateral concession giving no rights of enforcement to the other party, and allowing denunciation at will. Arguments of this kind had been articulated in the 19th Century - such as when the Tsar of Russia abolished the status of Batoum as a 'free port' as guaranteed by Article 59 of the Treaty of Berlin of 1878, on the basis that such a status was essentially a 'privilege' rather than a reciprocal entitlement. ${ }^{162}$ And they proceeded to be enunciated once again by Turkey in its denunciation of the capitulation agreements in 1923 prior to the conclusion of the Treaty of Lausanne, ${ }^{163}$ and by China in its campaign for revision at the Washington Conference. ${ }^{164}$

A curious feature of the intellectual development in the law of treaties in the 20th Century was that the willingness to embrace the analogy between

${ }^{159}$ C. Triepel, Völkerrecht und Landesrecht (Leipzig, 1899) p. 53.

${ }^{160}$ A Vertrag consisted of the classic contractual formula in which one party committed itself to doing $\mathrm{X}$ in return for the other doing Y. A Vereinbarung, by contrast, consisted of each party committing itself to achieve the same aims.

${ }^{161}$ See generally, Lauterpacht, supra note 121, pp. 155-8; A. McNair, 'The Functions and Differing Legal Character of Treaties', 11 British Yearbook of International Law (1930) p. 106; Réglade, 'De la nature juridique des traités internationaux et du sens de la distinction des traitéslois et des traits-contrats', 41 Revue du droit public et de la science politique (1924) p. 505.

${ }^{162} \mathrm{McNair}$, supra note 99, p. 355. An ensuing dispatch from Lord Rosebery objected to the Russian characterisation of the regime insisting that since the provisions were contained in treaty form, a right of unilateral denunciation was thereby precluded.

${ }^{163}$ Statement of Ismet Pasha, Turkish Delegate at Lausanne Conference, cited in Woolsey, supra note 112, p. 347 ("As a matter of fact, the Capitulations are essentially unilateral acts. In order that an act may be regarded as reciprocal, it must above all contain reciprocal engagements. From an examination of the texts, the evidences shows that in granting the privileges in question to foreigners in Turkey, the Ottoman emperors had no thought of obtaining similar privileges in favour of subjects travelling or trading in Europe. It is for this reason that Féraud Giraud says: 'These acts are not so much international treaties as grants of privileges'.”) See generally, Thayer, supra note 41, pp. 224-5.

${ }^{164}$ See W. Chin, V.K. Wellington Koo's Foreign Policy (Kelly and Walsh, Shanghai, 1931), passim. 
treaties and contracts occurred at the same time at which lawyers were becoming increasingly aware of the sheer diversity of agreements that were to be embraced under that title. In an article written in 1930, shortly after the publication of Lauterpacht's Analogies, McNair lamented international lawyers' reliance upon a singular set of universal rules when dealing with 'the only and sadly overworked instrument with which international society is equipped for the purpose of carrying out its multifarious transactions', vis 'the treaty'. ${ }^{165}$ For McNair, various distinctions had to be recognised between the 'conveyance' or the 'charter of incorporation' and the 'contract', between the 'contract' and the 'law-making treaty', and between treaties creating 'Constitutional International Law' and those creating or declaring 'ordinary International Law'. Such distinctions, for McNair, all had a significance that went far beyond their mere form, and affected questions such as their interpretation, their continued applicability during war, their effects on third parties, and the possibilities arising for unilateral termination. He concluded by arguing that "we" (international lawyers) needed to "free ourselves from the traditional notion that the instrument known as the treaty is governed by a single set of rules, however inadequate, and set ourselves to study the greatly differing legal character of the several kinds of treaties and to frame rules appropriate to the character of each kind". ${ }^{166}$

To the extent that the Vienna Convention on the Law of Treaties makes a number of concessions to the different characteristics of treaties - for example in Article 60(5) (concerning the inadmissibility of termination following material breach in case of humanitarian treaties), and Article 62(2)(a) (concerning the impermissibility of invoking a fundamental change in circumstance in relation to treaties establishing a boundary) - McNair's point appears to have sunk home. By the same token, it is apparent that neither McNair nor the drafters of the Vienna Convention were particularly concerned with interrogating the initial assumption as to the pertinence of the analogy between treaties and contracts: what was being described was merely the variegation between different forms of contractual obligation, a variegation that gave rise to the modification of general rules in particular contexts. There was still only one 'law of treaties', it was just that the rules were rather more nuanced and their application in particular contexts made dependent upon the 'object and purpose' of the agreement. ${ }^{167}$

In order for the law of treaties to be cast in such a way as to encompass the range of instruments that were in use, however, the understanding of what

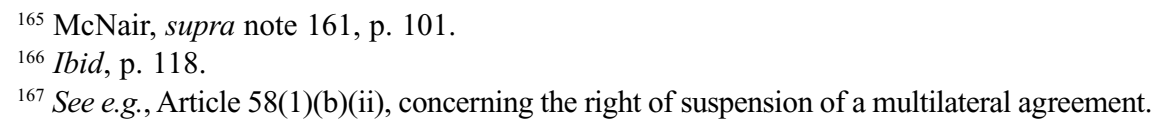


constituted an 'agreement governed by international law' had to be articulated in suitably abstract form. It was not possible, in that context, to insist upon the existence of substantive reciprocity between the parties as, apart from anything else, many multilateral agreements seemed to assume the shape of Triepel's Vereinbarung - agreements in which States committed themselves to pursuing a common policy rather than for purposes of exchanging goods, benefits or services in the classical contractual sense. The Comments of the ICJ in the Reservations case to the effect that in respect of treaties such as the Genocide Convention "one cannot speak of individual advantages or disadvantages to States, or of the maintenance of a perfect contractual balance between rights and duties" 168 were all too prescient in the context of the ongoing process of multilateral law-making. It is of no great surprise, therefore, that the drafters of the Vienna Convention eschewed any mention of reciprocity or exchange in their definition of what constitutes a valid agreement. ${ }^{169}$

If one could not demand reciprocity in the context of multilateral agreements constituted for purposes of enhancing the interests of international solidarity (the environment, human rights and so on), however, so it also would be impossible to insist that a lack of reciprocity provided a way of avoiding 'one-sided' agreements. Reciprocity was something that may, or may not, characterise an agreement and was relevant only so far as it was descriptive of the entitlements participating States were to be accorded. In such a context, the concerns of those opposed to unequal treaties became incapable of effective articulation: they would either have to broaden their attack to include a much wider range of instruments than those associated with the original doctrine, ${ }^{170}$ or simply accept that so long as the agreements were duly signed and ratified by both contracting parties nothing more would be needed for purposes of establishing their validity under international law.

Apart from the way in which this logic was such as to create the intellectual space for the later articulation of binding unilateral declarations ${ }^{171}$ it was also to expose the precarious nature of international lawyers' commitment to

${ }^{168}$ Reservations to the Convention on the Prevention and Punishment of the Crime of Genocide, ICJ Reports 1951, p. 23.

${ }^{169}$ Article 2(1)(a) defines a treaty as "an international agreement concluded between States in written form and governed by international law, whether embodied in a single instrument or in two or more related instruments and whatever its particular designation".

${ }^{170}$ Thus the list of 'unequal treaties' drawn up by the People's Republic of China in the late 1960s included, amongst other things, the Nuclear Test Ban Treaty of 1963 and the NonProliferation Convention of 1968. See, Chiu H., The People's Republic of China and the Law of Treaties (Harvard University Press, Cambridge, MA, 1972) pp. 66-68.

${ }^{171}$ Cf. Nuclear Tests Case (Australia v. France) ICJ Rep. 1974, para. 43 ("It is well recognized that declarations made by way of unilateral acts, concerning legal or factual situations, 
the idea of reciprocity more generally. ${ }^{172}$ On the one hand, reciprocity has come to be understood, as Simma suggests, as a "constructive, mitigating and stabilising force", lying behind "attempts both to curtail the extremes of power politics and to organise international co-operation for human welfare". ${ }^{173}$ Understood, in other words, as a condition under which each State must accord, to every other, the same benefits of international law (to allow, in particular, reciprocal reliance upon legal arguments by the State against which they are employed), it sets itself against the creation of hierarchies of entitlement, or a system of law that is differentiated, at the outset, by conditions of power.

On the other hand, however, reciprocity can also have quite different connotations. If reciprocity is understood, not as a general correlate to the principle of equality before the law, but as an insistence upon a bilateral understanding of obligation it seems to operate as a barrier to sentiments of solidarity, obstructing endeavours to promote the general societal interest (as, in particular, may be expressed in the notion of erga omnes rights or obligations). Insisting, for example, that every legal commitment has to be articulated in terms of a dyadic relationship of rights and obligations between

may have the effect of creating legal obligations ... When it is the intention of the State making the declaration that it should become bound according to its terms, that intention confers on the declaration the character of a legal undertaking, the State being thenceforth legally required to follow a course of conduct consistent with the declaration ... In these circumstances, nothing in the nature of a quid pro quo nor any subsequent acceptance of the declaration, nor even any reply or reaction from other States, is required for the declaration to take effect, since such a requirement would be inconsistent with the strictly unilateral nature of the juridical act by which the pronouncement of the State was made.").

${ }^{172} C f$. D. Kennedy, 'Theses about International Law Discourse', 23 German Yearbook of International Law (1980) p. 373, note 23 ("reciprocity will not tell a state whether it prefers a world in which states respect treaties or in which they do not ... Either strictness or mercy may be reciprocal. At this point one is returned to a decision to follow or break the treaty ... $[T]$ reaty breaking is associated with national autonomy, and following with international solidarity. But the reverse may as well be true. To release a State from a harsh treaty may be expression of merciful community solidarity, while to hold a state to such a treaty may be an expression of national autonomy.").

${ }^{173}$ B. Simma, 'Reciprocity', in R. Bernhardt (ed.), Encyclopedia of Public International Law (North-Holland, Amsterdam, New York, 1984) p. 400. And further:

"As a horizontal legal system, international law rests upon the logic of reciprocity in its entirety. Reciprocity is at work not only behind the long-established "traffic rules" of routine international relations but also with equal force behind the legal, irrespective of the political and ideological antagonisms that divide the contemporary world".

Byers remarks, in similar vein, that reciprocity, understood as a "legal consequence of the formal equality of States", is an idea which "qualifies the application of power" in various ways. Byers, supra note 9, p. 80. 
individual States, may arguably distort the communal or societal interests in question and lead to evident problems concerning the identification of those who may regard themselves as having a legitimate interest in compliance. ${ }^{174}$ Non-reciprocity, when opposed to a bilateralist conception of obligation, seems to speak therefore of community and solidarity - it represents the possibility of creating general, public, obligations (with respect to the environment or human rights for example) that transcend the private framework of the contract.

Reciprocity, therefore, appears to be janus-faced. Depending upon which of these understandings is employed, the notion of non-reciprocity may alternatively be associated with collaborative efforts to promote social solidarity and co-operation (in which the non-reciprocal, 'objective', regime would seem to be archetypal), or with the institution of overtly inegalitarian, hierarchical, relationships within the framework of international law (as represented paradigmatically by the classical 'unequal treaty'). That non-reciprocity shows itself to have both such faces, however, not only has resonance for purposes of opposition to 'unequal treaties', but also for the nature of the 'communal' or 'societal' endeavours in question. Just as the existence of 'objective' regimes renders more difficult the articulation of concerns relating to the essential substantive inequality of agreements, so also the historic shadow of unequal treaties makes more problematic the assertion that the values instantiated within the objective regimes themselves are indeed communal ones.

\section{Conclusions}

To turn back, then, to the three grounds upon which the 19th Century treaties were challenged for their inequality, we are faced with a partial answer to merely one of them - that of duress. As regards the other elements - the subordination of sovereignty, and the absence of reciprocity - the so-called 'development' of international law in the hands of 20th Century international lawyers has effectively removed them from the frame. Neither the claim that a treaty breaches a State's sovereignty, nor that an agreement is voidable by reason only of being non-reciprocal, is open to serious contemplation - both sovereignty and reciprocity have come to mean something less (or at least something different) than that entailed here. If anything, such notions have been evacuated of meaningful content to the point at which they serve only

\footnotetext{
${ }^{174}$ On this issue generally see, M. Craven, 'Legal Differentiation and the Concept of the Human Rights Treaty in International Law', 11 European Journal of International Law (2000) p. 489.
} 
a broadly descriptive role: limits on sovereignty or lack of reciprocity merely describing the sort of agreement in contemplation rather than being matters that condition arguments as to their authority or legitimacy. If it is the case, however, that the latent conditions for the persistence of unequal treaties remain intact, the enduring significance of the doctrine would appear to rest upon the extent to which one might be able to identify, within the context of current treaty relations, the continuance of colonial models of power and authority.

What is particularly evident in the narrative outlined above, however, is the significance of formal modes of domination for international lawyers' understanding of their own discipline and its engagement with colonial history. As was classically the case with respect to the Leninist conception of imperialism, ${ }^{175}$ the history of the colonial encounter appears to be almost uniformly understood in terms of the establishment, and disestablishment, of colonial rule, thus rendering peripheral the engagement with powers in East Asia. Even critics, such as Anghie take the view that "it was principally through colonial expansion in the nineteenth century that international law became universal" 176 and that "the colonial confrontation was not a confrontation between two sovereign states, but between a sovereign European state and a non-European state that . . was lacking in sovereignty." ${ }^{177}$ For all of the profound insights that Anghie's analysis brings to the study of the relationship between international law and colonialism, the approach is such as to encourage a focus upon the problem of colonialism in terms of sovereignty, territorial title, and associated concepts such as terra nullius and uti possidetis. Colonialism comes to be equated, in that regard, with a particular type of practice, and a particular type of rule, which was effective, furthermore, only in relation to some, but not all parts of the non-European world. This, no doubt, is bolstered by the more mainstream understanding given to the process of decolonisation which, again, has tended to be understood in the same terms - being achieved by way of the granting of political independence to colonial territories and in the creation of new sovereign States out of the embers of the old maritime empires. For all the continuing debate as to the limits of political self-determination in the context of economic dependency, the precepts colonialism and decolonisation are more redolent in international lawyers' eyes of particular types of political arrangement, rather than regimes of economic exploitation.

What is evidently problematic about this focus is not merely the temporal and spatial limitations associated with this understanding of colonialism

\footnotetext{
175 Supra, note 35.

${ }^{176}$ Anghie, supra note 147, p. 516.

${ }^{177}$ Anghie, supra note 63, p. 3.
} 
(here, not there; then, not now), but that its insistence upon foregrounding problems of sovereignty and territorial title comes at the expense of what appears to have been particularly distinctive about colonialism as a practice. It was not, as Anghie and others readily accept, merely about subjugation or rule, but about subjugation for a purpose - whether that be to civilise or exploit (or both). In that sense, the experience of China, Siam and Japan appears to have been far more central to the colonising mission than might otherwise be supposed: they were subjected to the full weight of a culturallyloaded international regime whose disciplinary thrust - both to open economies to external trade on propitious terms, and to 'civilise the natives' by insisting upon legal and administrative reform - was largely indistinguishable from that associated with formal colonial rule.

But the obvious point, here, is that once the framework of colonialism is widened to include such informal modes of domination, its possible endurance beyond the stage of formal decolonisation becomes all the more problematic. The persistence, in that context, of the ghost of a 19th Century concept of unequal treaties which was so evidently the medium by which colonialism was extended beyond the framework of formal rule, brings into question the implications of formal 'decolonisation', and the possible endurance of the colonising mission in a range of activities that continue to the present day. Whether one thinks in terms of non-reciprocal human rights agreements, or agreements to promote free trade or the protection of foreign investments, the parallels with 19th Century extraterritorial regimes predicated upon maintaining the 'open door', insulating traders and investors from the arbitrary excesses of local law, and promoting humanitarian ideals appear all too obvious. There is, at the very least, a question to answer here - and one which is imprinted, as much as anything else, in international lawyers' unwillingness to engage effectively with the problem of inequality. 